Historic, archived document

Do not assume content reflects current scientific knowledge, policies, or practices. 


\section{United States Department of Agriculture}

Forest

Service

North Central

Forest Experiment

Station

Resource

Bulletin NC-138

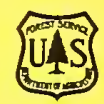

\section{Forest Statistics for Minnesota's Prairie Unit}

Sue M. Roussopoulos

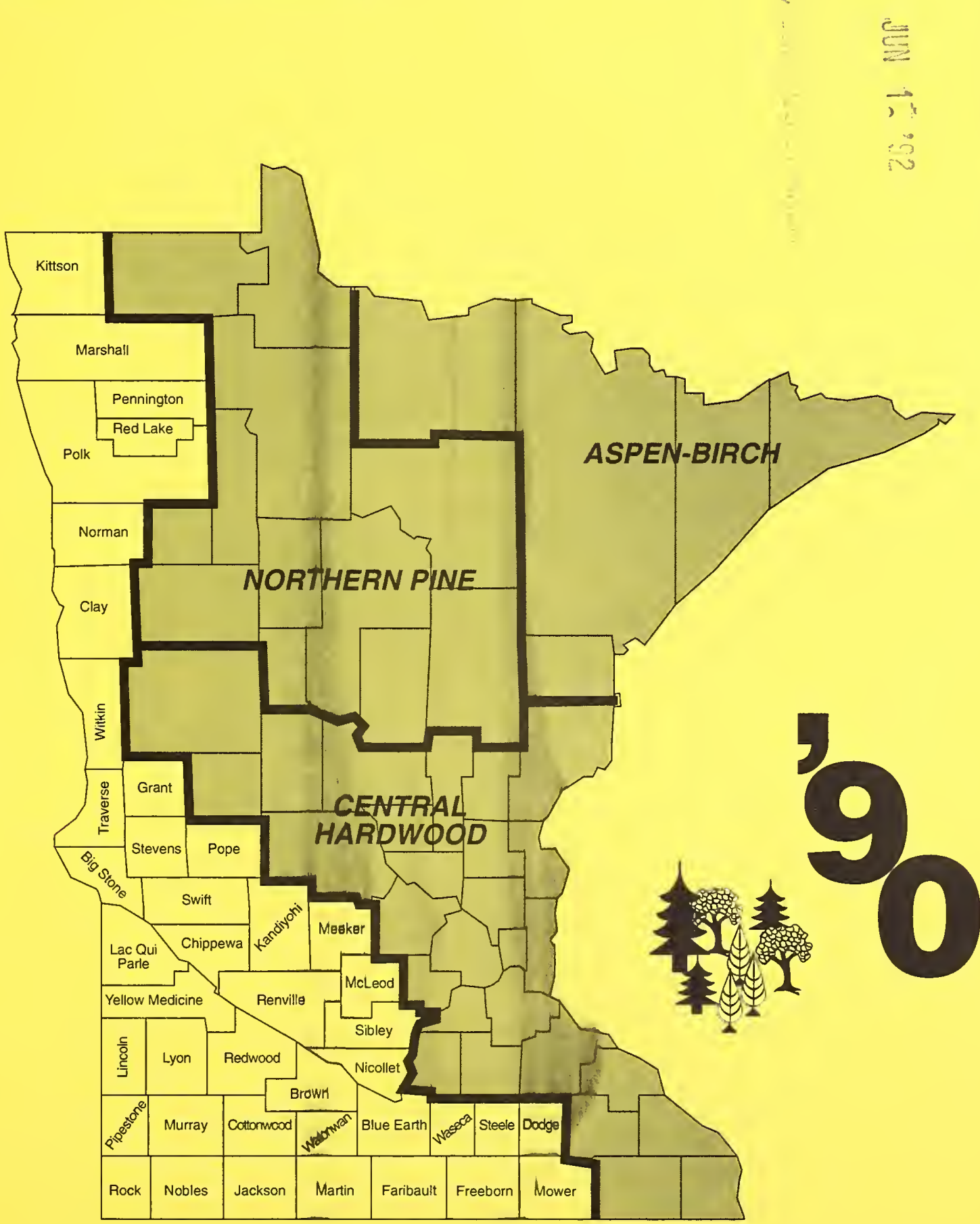


This report includes the most commonly used Forest Inventory and Analysis statistics. Additional forest resource data can be provided to interested users. Persons requesting additional information from the raw inventory data are expected to pay the retrieval costs. These costs range from less than $\$ 100$ for a relatively simple request to $\$ 2,000$ for a complex retrieval involving the services of a Forest Inventory and Analysis computer programmer. Requests will be filled so as to minimize the impact on the Forest Inventory and Analysis Work Unit.

Requests for information may be directed to:

\author{
Project Leader \\ Forest Inventory and Analysis \\ North Central Forest Experiment Station \\ 1992 Folwell Avenue \\ St. Paul, Minnesota 55108 \\ Phone: (612) 649-5139 \\ or \\ State Forester \\ Minnesota Department of Natural Resources \\ Forestry Division \\ P.O. Box 44 \\ 500 Lafayette Road \\ St. Paul, Minnesota 55146 \\ Phone: (612) 296-6491
}

Area served: Illinois, Indiana, Iowa, Kansas, Michigan,

Minnesota, Missouri, Nebraska, North Dakota,

South Dakota, Wisconsin

North Central Forest Experiment Station

Forest Service - U.S. Department of Agriculture

1992 Folwell Avenue

St. Paul, Minnesota 55108

Manuscript approved for publication March 16, 1992 


\section{FOREWORD}

Forest Inventory and Analysis (FIA) is a continuing endeavor as mandated by the Renewable Resources Research Act of 1978. Prior inventories were mandated by the McSweeney-McNary Forest Research Act of 1928. The objective of FIA is to periodically inventory the Nation's forest land to determine its extent, condition, volume of timber, growth, and removals. Up-to-date resource information is essential to frame forest policies and programs. USDA Forest Service regional experiment stations are responsible for conducting these inventories and publishing summary reports for individual States. The North Central Forest Experiment Station is responsible for forest inventory and analysis in Illinois, Indiana, Iowa, Kansas, Michigan, Minnesota, Missouri, Nebraska, North Dakota, South Dakota, and Wisconsin.

Fieldwork for the Minnesota Prairie Unit forest inventory was begun in February 1990 and completed in February 1991. Reports of four previous inventories of Minnesota's timber resource are dated 1936, 1953, 1962, and 1977.

More accurate survey information was obtained during this survey than otherwise would have been feasible because of intensified field sampling. This sampling was made possible through the cooperation and assistance of the Minnesota Department of Natural Resources (MDNR). To aid in determining current timber removals, the MDNR also surveyed primary wood-using plants in the State.

Aerial photos used in the Prairie Unit forest inventory were 1:40,000 scale black and white photos furnished by the USDA Agricultural Stabilization and Conservation Service. In addition, MDNR provided $35 \mathrm{~mm}$ true color prints at a scale of $1: 15,840$ of all of the 1977 plot locations for disturbance detection. 


\section{Contents}

Highlights ....................................................................... 1

General ........................................................................ 1

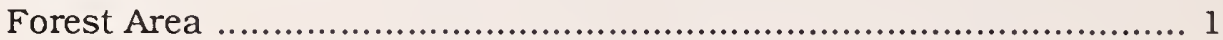

Volume ............................................................................ 3

Timber Growth, Mortality, and Removals .................................... 3

Appendix ...................................................................... 4

Accuracy of the Survey ..................................................... 4

Survey Procedures .......................................................... 6

Comparing Minnesota's Fifth Inventory with the Fourth Inventory .... 10

Tree Grade .................................................................. 11

Metric Equivalents of Units Used in this Report ......................... 16

Tree Species Groups in Minnesota ........................................ 16

Definition of Terms ............................................................... 17

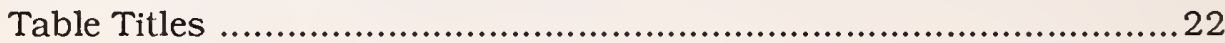




\title{
Forest Statistics for Minnesota's Prairie Unit
}

\author{
Sue Roussopoulos
}

\section{HIGHLIGHTS}

NOTE: Data from new forest inventories are often compared with data from earlier inventories to determine trends in forest resources. However, for comparisons to be valid, the procedures used in the two inventories must be similar. As a result of our ongoing efforts to improve inventory efficiency and reliability, several changes in procedures and definitions have occurred since 1977. Because some of these changes will make it inappropriate to directly compare the 1990 data with those published for 1977, data from the 1977 inventory have been reprocessed using the 1990 procedures. Please refer to the Appendix section labeled "Comparing Minnesota's Fifth Inventory With the Fourth Inventory" for more details. The data in this report are subject to change when inventory data for the entire State have been compiled. It is expected, however, that any such changes will be minor.

\section{General}

The Prairie Survey Unit consists of 42 counties stretching from southeastern Minnesota northwest to the Canadian border (see cover illustration). Before settlement, the region was dominated by tallgrass prairie with scattered groves of oaks and gallery forests to the south and aspen parklands to the north (Wendt and Coffin

Sue M. Roussopoulos, Resource Analyst, began her career with the Forest Service at the Rocky Mountain Station in Fort Collins, Colorado in 1980. She joined North Central's Forest Inventory and Analysis Unit in 1989.
$1988^{1}$ ). Frequent fires helped maintain the species composition and treeless nature of the prairie. Today the tallgrass prairie has all but disappeared as agricultural crops now blanket the landscape and trees remain only a minor component of the landscape. Less than 4 percent of the Prairie Unit's 19.1 million acres is forested. Although small in area, these forests are vital in protecting the landscape. They serve as windbreaks, shelterbelts, and wildlife corridors, and they protect against streamside erosion. This bulletin presents statistical highlights of the fifth inventory of Minnesota's Prairie Survey Unit and contains detailed tables of information about forest area, as well as timber volume, growth, removals, mortality, and ownership.

\section{Forest Area}

- The Prairie Survey Unit contains 19.1 million acres of land, of which only 3.4 percent or 660 thousand acres are forested (fig. 1). With 139 thousand acres of forest land, Marshall County in northwestern Minnesota is the most heavily forested county in the Unit. Current forest area includes more than 7,500 acres of reserved forest land where harvesting is prohibited by statute or administrative designation.

- Total forest land in the Unit increased by 15 percent from 573 thousand acres in 1977 to 660 thousand acres in 1990. Ninety-seven percent of forest land in the Unit is timberland, up from 93 percent in 1977.

\footnotetext{
${ }^{1}$ Wendt, Keith M.; Coffin, Barbara A. 1988. Natural vegetation of Minnesota at the time of the Public Land Survey, 1847-1907. Biol. Rep. 1. St. Paul, MN: Minnesota Department of Natural Resources. 6 p.
} 


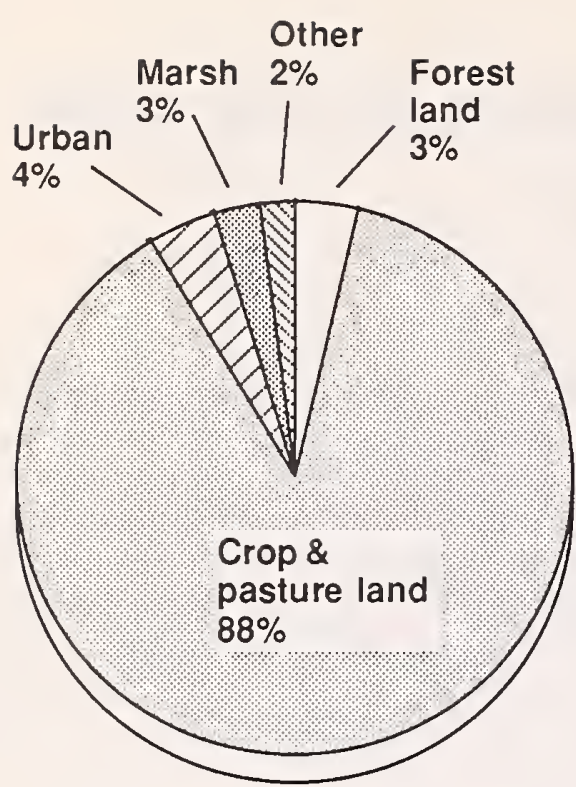

Figure 1.-Distribution of land types in the Prairie Unit, 1990.

- Timberland area increased by 110 thousand acres between inventories. Timberland is forest land that is capable of producing more than 20 cubic feet of wood per acre annually and that is not withdrawn from utilization. Forty-eight percent of all timberland in the Unit is found in the five northernmost counties that make up only 20 percent of the Unit's land area.

- Eighty-five percent of the Prairie Unit's timberland is held by private land owners (fig. 2). Farmers own 68 percent of private timberland; other individuals and corporations own 28 and 4 percent, respectively. The remaining 15 percent is public-owned timberland, of which the State owns nearly 80 percent.

- Four forest types account for more than 90 percent of timberland area in the Unit (fig. 3). Aspen is still the predominant forest type. accounting for one-third of timberland area. An early succession type, aspen declined by 35 thousand acres (14 percent) between 1977 and 1990; the more shade tolerant maplebasswood type increased by 73 thousand

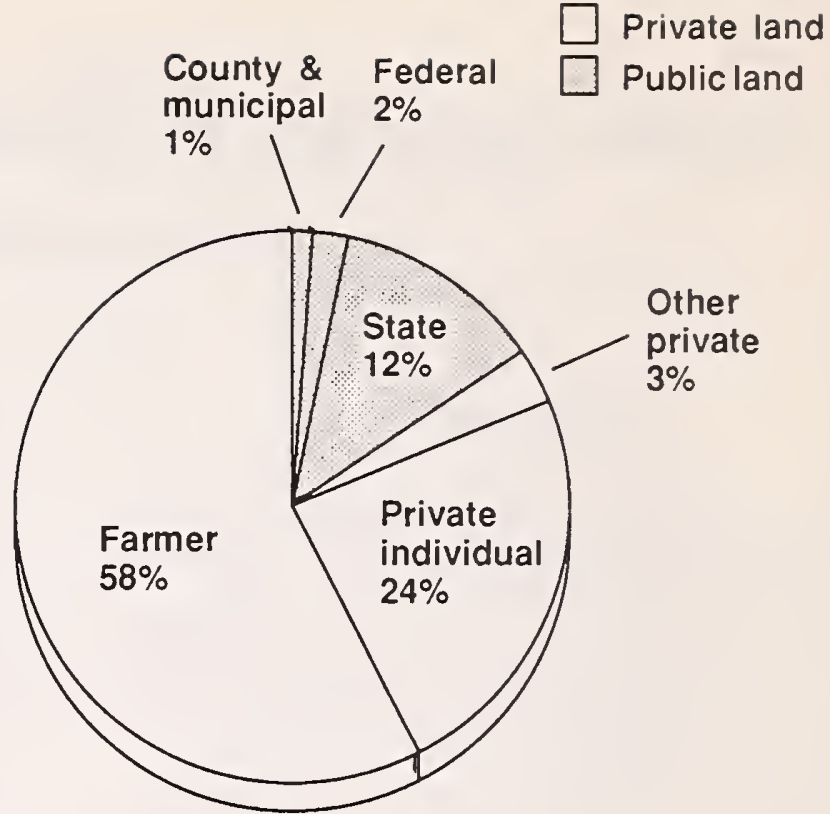

Figure 2.-Distribution of timberland in the Prairie Unit by ownership class, 1990.

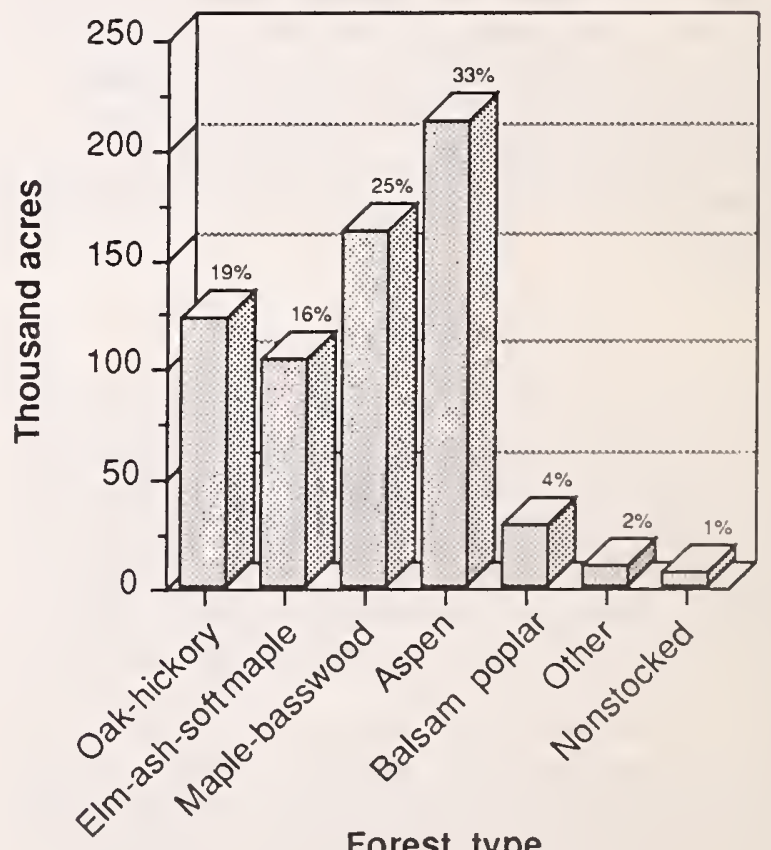

Figure 3.-Area of timberland in the Prairie Unit by forest type, 1990. 
acres (83 percent) and now accounts for 25 percent of timberland area. Oak-hickory and elm-ash-soft maple are 19 and 16 percent of timberland area, respectively.

- Sawtimber and sapling-seedling stands make up 49 and 27 percent of timberland area, respectively. The area of poletimber, the predominant stand size in 1977, decreased as stands grew into sawtimber. Poletimber now accounts for 23 percent of area. About 1 percent of timberland area is nonstocked.

- Sixty-one percent of timberland area in the Prairie Unit is moderately or fully stocked with growing-stock trees. Only 7 percent is overstocked.

\section{Volume}

- The volume of timber in the Prairie Survey Unit totaled 565 million cubic feet in 1990 . an increase of 24 percent from 1977. Average volume per acre is 878 cubic feet.

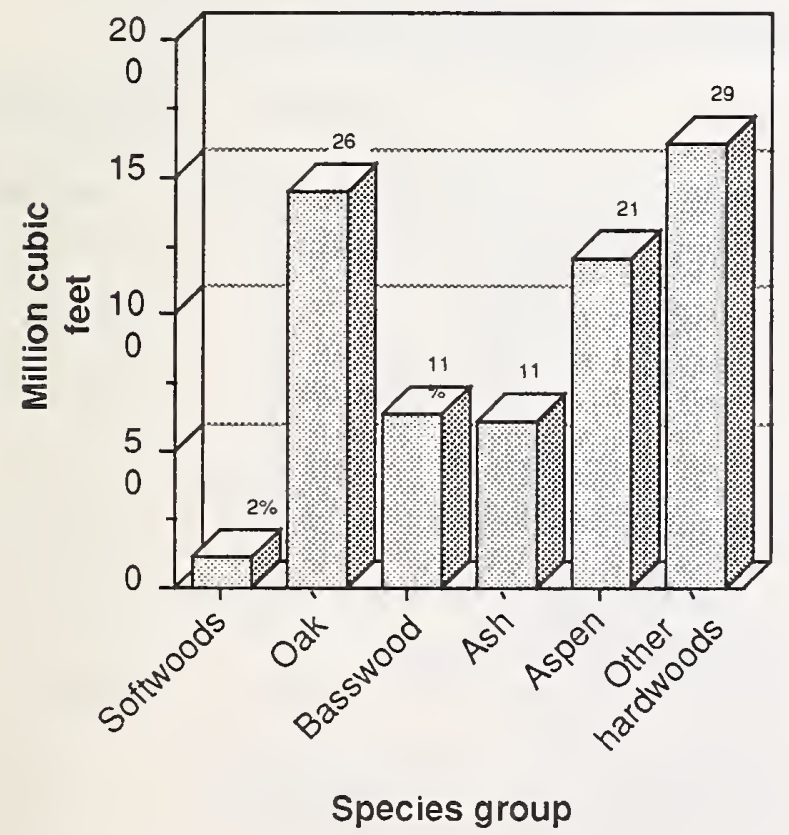

Figure 4.-Volume of growing stock on timberland in the Prairie Unit by species group, 1990.
- Together, oaks make up 26 percent of the 555 million cubic feet of hardwood growingstock volume, followed by aspen at 22 percent (fig. 4). Basswood and ash account for another 12 and 11 percent of hardwood volume, respectively. Only 2 percent of growing-stock volume is in softwoods.

- Sawtimber volume totaled 1.6 billion board feet in 1990, an increase of 37 percent over the 1.2 billion board feet estimated in 1977 . Sawtimber volume averaged 2,496 board feet per acre in 1990.

- Eighty-nine percent of growing-stock volume was on private timberland in 1990 with nearly two-thirds held by farmers (fig. 5). Public timberland volume was 64 million cubic feet. Average volume per acre for private land was 919 cubic feet compared to 653 for public land.

\section{Timber Growth, Mortality, and Removals}

- Average net annual growth of growing stock from 1977 to 1989 was 11.7 million cubic

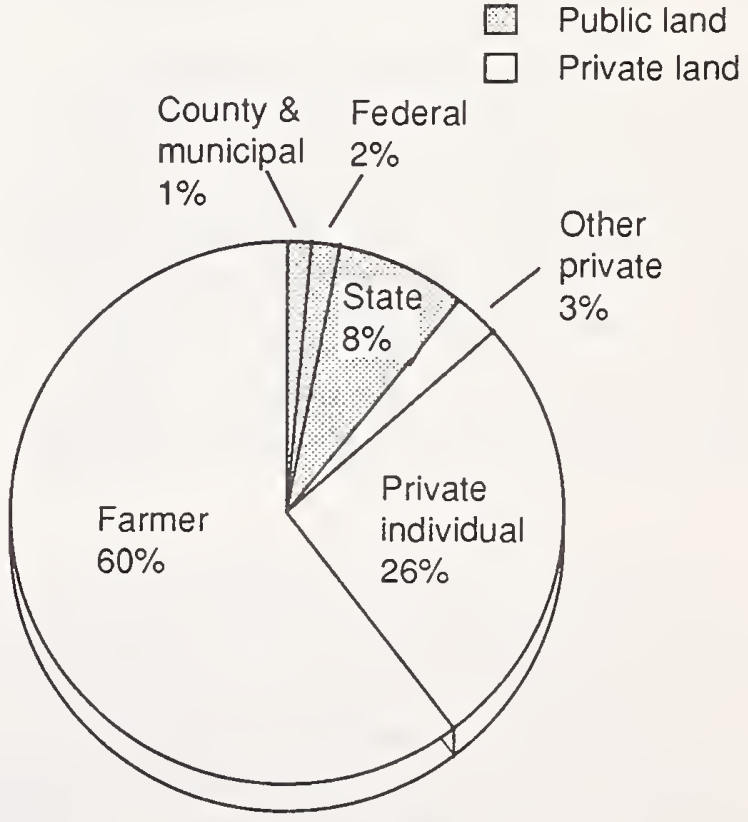

Figure 5.-Distribution of growing-stock volume on timberland in the Prairie Unit by ownership class, 1990. 
feet (fig. 6). This is an average of 18 cubic feet per acre per year.

- Annual growing-stock mortality averaged 9.1 million cubic feet or 14 cubic feet per acre from 1977 to 1989. Together, elm (3.4 million cubic feet) and aspen ( 2.9 million cubic feet) accounted for 70 percent of hardwood average annual mortality.

- Average annual removals of growing stock on timberland for 1977 through 1989 was 7.2 million cubic feet or 61 percent of net average annual growth. Virtually all removals were hardwoods.

- In 1989, growth of growing stock on timberland was 18.2 million cubic feet, or 3 percent of inventory. This is an average of 28 cubic feet per acre per year.

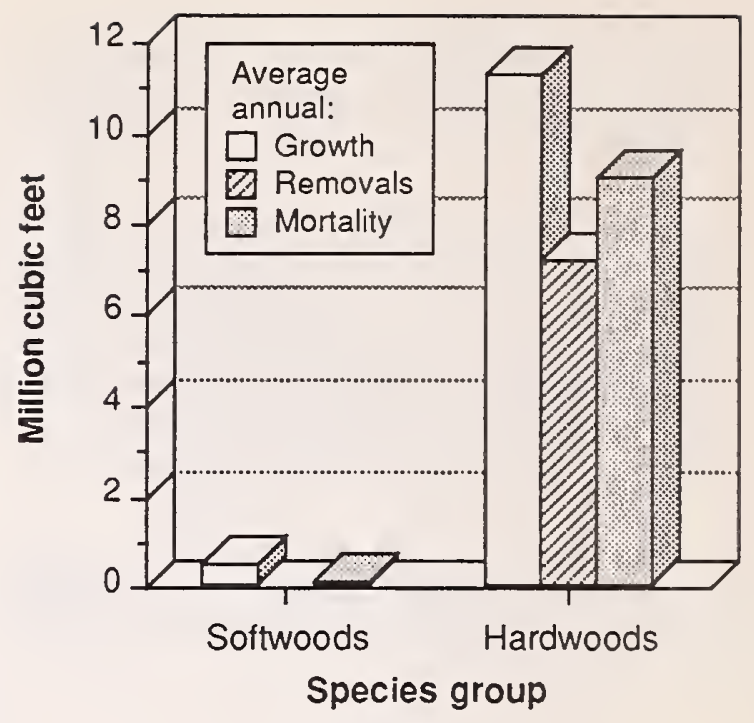

Figure 6.-Average annual growing-stock growth, removals, and mortality on timberland in the Prairie Unit by species group, 19771990.

\section{APPENDIX}

\section{ACCURACY OF THE SURVEY}

Forest Inventory and Analysis information is based on a sampling procedure designed to provide reliable statistics at the State and Survey Unit levels. Consequently, the reported figures are estimates only. A measure of reliability of these figures is given by sampling errors. These sampling errors mean that the chances are two out of three that if a 100percent inventory had been taken, using the same methods, the results would have been within the limits indicated.

For example, the estimated growing-stock volume in the Unit in $1990,565.4$ million cubic feet, has a sampling error of \pm 4.1 percent $( \pm 23.2$ million cubic feet). The growing-stock volume from a 100-percent inventory would be expected to fall between 542.2 and 588.6 million cubic feet (565.4 \pm 23.2$)$, there being a one in three chance that this is not the case.
The following tabulation shows the sampling errors for the Prairie Forest Inventory:

Item

Unit totals Sampling error

$\begin{array}{lcc}\text { Growing stock } & \text { Million cubic feet } & \text { Percen } \\ \text { Volume (1990) } & 565.4 & 4.11 \\ \begin{array}{l}\text { Average annual growth } \\ \text { (1977-1989) }\end{array} & 11.7 & 9.38 \\ \begin{array}{l}\text { Average annual removals } \\ (1977-1989)\end{array} & 7.2 & 17.10\end{array}$

$\begin{array}{lc}\begin{array}{l}\text { Sawtimber } \\ \text { Volume (1990) }\end{array} & \text { Million board feet } \\ \text { Average annual growth } & 1,607.2 \\ \text { (1977-1989) } & 41.4 \\ \begin{array}{l}\text { Average annual removals } \\ \text { (1977-1989) }\end{array} & 18.7 \\ & \\ \text { Timberland } & \text { Thousand acres } \\ \text { area (1990) } & 643.8\end{array}$


NOTE: A standard FLA inventory is designed to provide sampling errors of 3 percent per million acres of timberland or an overall error on Minnesota's nearly 15 million acres of about 0.8 percent. The State of Minnesota funded the collection of additional field data to reduce the sampling error by one-half. The overall goal was to provide a sampling error for total timberland area by county of less than 10 percent.

The sampling error within a county depends on county size and total area of timberland. Many large, heavily forested counties in the State have sampling errors well below \pm 5 percent. However, in counties where timberland area is less than 35,000 acres, sampling errors generally exceed \pm 10 percent. This is often the case in the Prairie Unit. For this reason we combined data for some counties in this report to provide reporting areas with sampling errors less than \pm 10 percent (fig. 7). The sampling error for total timber volume in a reporting unit containing 35,000 acres of timberland will be about \pm 20 percent. Individual county data are provided only in table 1 with the associated sampling error for timberland. Other data for individual counties are available from FLA by special request. However, due to the large sampling errors associated with countylevel data, we urge you to use the grouped data when possible.

To estimate the sampling error for values smaller than Unit totals in this report, the following formula is used:

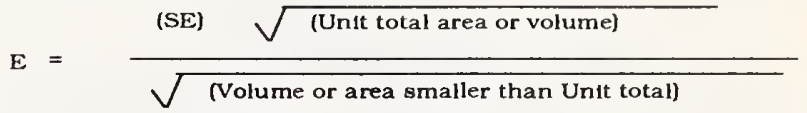

where:

$\mathrm{E}=$ sampling error in percent

$S E=$ Unit total error for area or volume

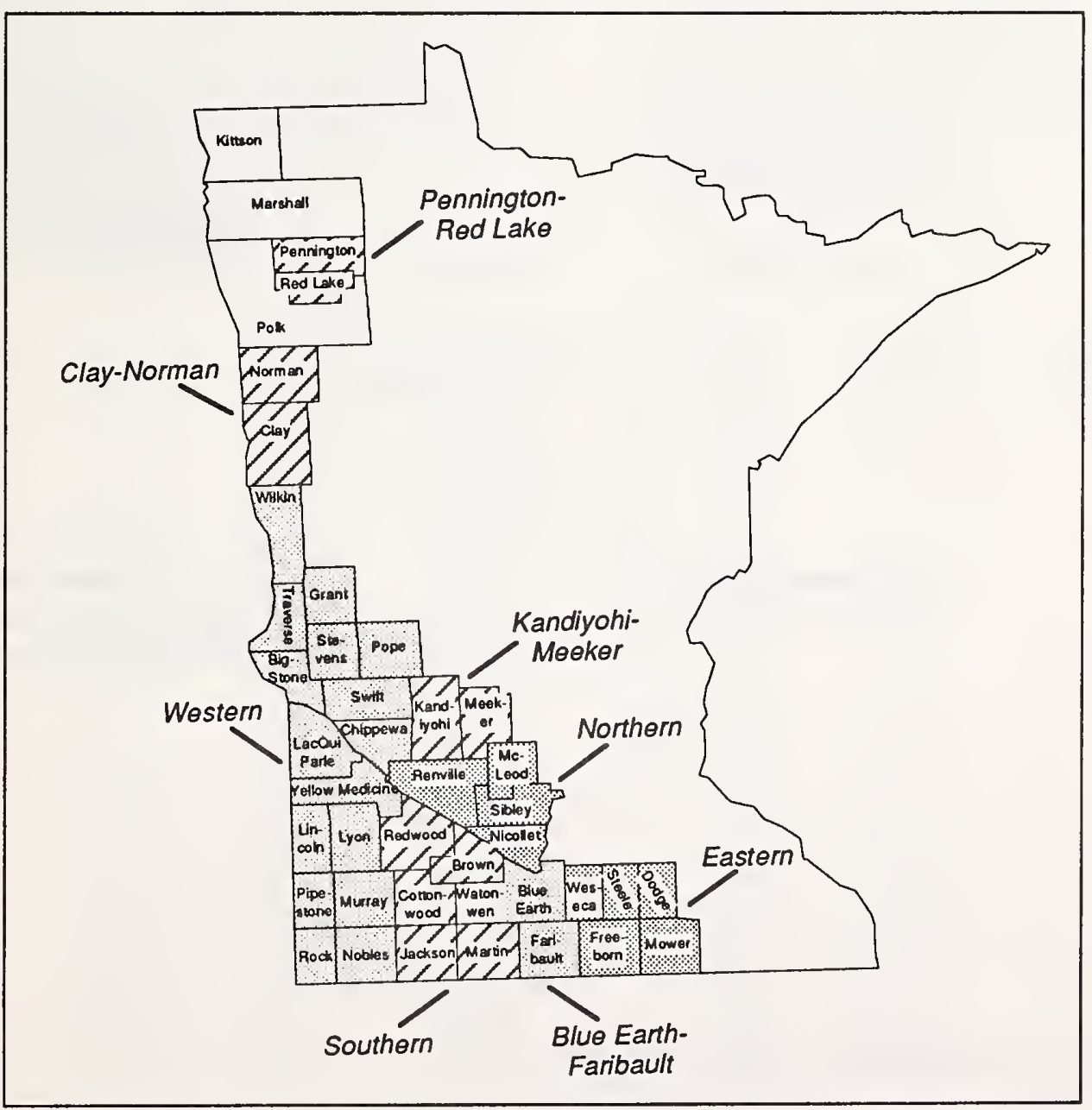

Figure 7.-Counties and grouped county reporting areas for the Prairie Unit, Minnesota. 
For example, to compute the error on the area of timberland in the elm-ash-soft maple in the Unit, proceed as follows:

The total area of elm-ash-soft maple type in the Unit from table $3=103.000$ acres

The total area of all timberland in the Unit from table $3=643,800$

The Unit total error for timberland area from the above tabulation $=2.36$ percent

Using the above formula:

$$
\begin{aligned}
\text { Error } & =\frac{(2.36) \sqrt{643,800}}{\sqrt{103,000}} \\
& = \pm 5.90 \text { percent }
\end{aligned}
$$

\section{SURVEY PROCEDURES}

The 1990 Minnesota survey used a growth model enhanced, two-phase sample design. Using this sampling scheme and associated estimators is similar to sampling with partial replacement (SPR), in that a set of randomly located plots is available for remeasurement and a random set of new plots is established and measured. A significant feature of the new Minnesota design is stratification for disturbance on the old sample and use of a growth model to improve regression estimates made on old undisturbed forest plots (fig. 8). Detailed descriptions of the sampling and estimation

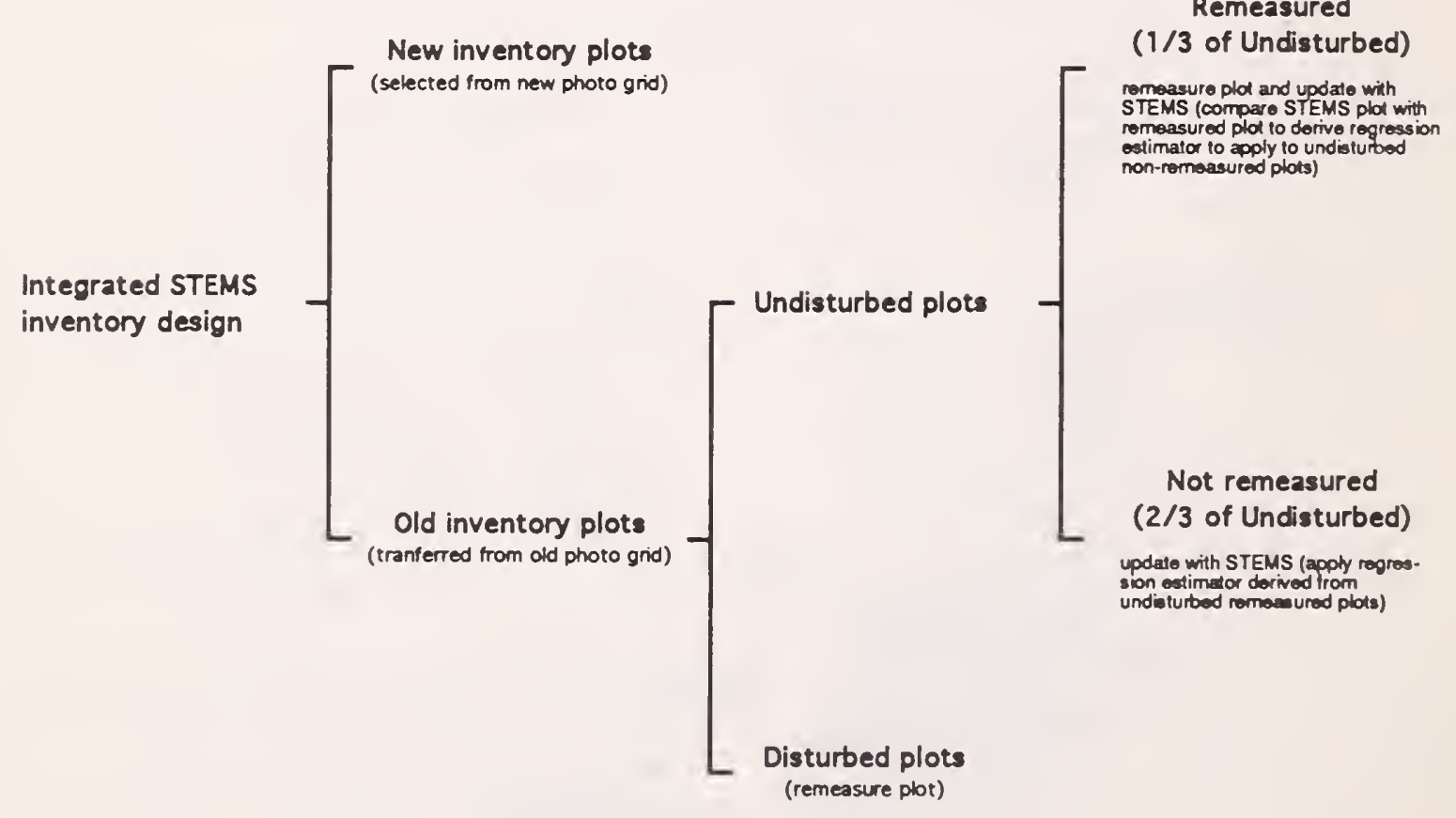

Figure 8.-Overview of the Minnesota sample design. 
procedures are presented by Hansen (1990) ${ }^{2}$. The growth model used in the Minnesota survey design was the Lake States Stand and Tree Evaluation and Modeling System (STEMS) ${ }^{3}$.

These were the major steps in the new survey design:

\section{Aerial photography (Phase 1)}

In this phase two sets of random points were located on current aerial photography. The first is a set of new photo plots and the second is a set of relocated old ground plot locations from the 1977 inventory. Aerial photos used in the Prairie Unit forest inventory were 1:40,000 scale black and white photos furnished by the Agricultural Stabilization and Conservation Service. In addition, the Minnesota Department of Natural Resources provided $35 \mathrm{~mm}$ true color prints at a scale of $1: 15,840$ of all of the 1977 ground plot locations. These $35 \mathrm{~mm}$ prints were used in addition to the ASCS prints to help detect disturbances in the 1977 ground plot locations. The year of photography for each county in the Unit is shown below.

\begin{tabular}{lrr} 
& \multicolumn{2}{c}{ Date } \\
\cline { 2 - 3 } County & $\mathbf{1 : 4 0 , 0 0 0}$ & $\mathbf{3 5 m m}$ \\
Big Stone & 1978 & 1988 \\
Blue Earth & 1980 & 1988 \\
Brown & 1978 & 1988 \\
Chippewa & 1978 & 1988 \\
Clay & 1981 & 1988 \\
Cottonwood & 1980 & 1988 \\
Dodge & 1980 & 1988 \\
Faribault & 1979 & 1988 \\
Freeborn & 1979 & 1988 \\
Grant & 1982 & 1988 \\
Jackson & 1979 & 1988 \\
Kandiyohi & 1979 & 1988 \\
Kittson & 1982 & 1988 \\
Lac Qui Parle & 1978 & 1988 \\
Lincoln & 1978 & 1988 \\
Lyon & 1978 & 1988 \\
Mc Leod & 1978 & 1988 \\
Marshall & 1982 & 1988 \\
Martin & 1980 & 1988 \\
Meeker & 1980 & 1988 \\
Mower & 1979 & 1988
\end{tabular}

The locations of the plots used in the 1977 inventory were transferred to these new photographs. The photographs were then assembled into township mosaics, and a systematic grid of 121 one-acre photo plots (each plot representing approximately 190.4 acres) was overlaid on each township mosaic. Each of these photo plots was examined by aerial photogrammetrists and classified stereoscopically based on land use. If trees were present, forest type and stand-size density class were recorded. All of the 1977 ground plot locations were also examined for disturbance (logging, fire, catastrophic mortality, etc.) with the aid of the $35 \mathrm{~mm}$ photographs.

${ }^{2}$ Hansen, Mark H. 1990. A comprehensive sampling system for forest inventory based on an individual tree growth model. St. Paul, MN: University of Minnesota, College of Natural Resources. 256 p. Ph.D. dissertation.

${ }^{3}$ Belcher, David W.; Holdaway. Margaret R.; Brand, Gary J. 1982. A description of STEMS the stand and tree evaluation and modeling system. Gen. Tech. Rep. NC-79. St. Paul, MN: U.S. Department of Agriculture, Forest Service, North Central Forest Experiment Station. $18 \mathrm{p}$.

\begin{tabular}{lcc}
\cline { 2 - 3 } County & $\mathbf{1 : 4 0 , 0 0 0}$ & $\mathbf{3 5 m} \mathbf{m}$ \\
Murray & 1979 & 1988 \\
Nicollet & 1978 & 1988 \\
Nobles & 1979 & 1988 \\
Norman & 1982 & 1988 \\
Pennington & 1982 & 1988 \\
Pipestone & 1979 & 1988 \\
Polk & 1982 & 1988 \\
Pope & 1982 & 1988 \\
Red Lake & 1982 & 1988 \\
Redwood & 1978 & 1988 \\
Renville & 1978 & 1988 \\
Rock & 1980 & 1988 \\
Sibley & 1980 & 1988 \\
Steele & 1980 & 1988 \\
Stevens & 1982 & 1988 \\
Swift & 1978 & 1988 \\
Traverse & 1980 & 1988 \\
Waseca & 1980 & 1988 \\
Watonwan & 1980 & 1988 \\
Wilkin & 1982 & 1988 \\
Yellow Medicine & 1978 & 1988
\end{tabular}


After this examination, all the old "disturbed" sample locations, a one-third sample of the old "undisturbed" sample locations, and a sample of the new photo plots were sent to the field for survey crews to verify the photo classification and to take further measurements. All photo plot locations for the 1990 inventory were examined for the Prairie Unit and were classified as shown in the following tabulation:

$\begin{array}{lr}\text { Photo land class } & \text { Photo plo } \\ & \\ \text { Timberland } & 12,294 \\ \text { Reserved forest land } & 326 \\ \text { Other forest land } & 146 \\ \text { Questionable } & 480 \\ \text { Nonforest with trees } & 1,404 \\ \text { Nonforest without trees } & 48,197 \\ \text { Water } & 3,285 \\ \text { All classes } & 66,132\end{array}$

\section{Plot measurements (Phase 2)}

On plots classified as timberland, wooded pasture, or windbreak (at least 120 feet wide), a ground plot was established, remeasured, or modeled. Old plots sent to the field for remeasurement that could not be relocated were replaced with a new plot at the approximate location of the old one. Each ground plot consists of a 10-point cluster covering approximately 1 acre. At each point, trees 5.0 inches or more in d.b.h. were sampled on a 37.5 Basal Area Factor (BAF) variable-radius plot, and trees less than 5.0 inches d.b.h. were sampled on a $1 / 300$-acre fixed-radius plot. The measurement procedure for the new and old sample locations was as follows:

\section{a. New inventory plots}

A random sample of the new photo plots was selected for field measurement. Ground plots were established, and measures of current classification such as land use, forest type, and ownership as well as size and condition of all trees on the plot were recorded. These locations were monumented for future remeasurement.

\section{b. Old inventory plots}

These plots were established, monumented, and measured as part of the 1977 field inventory. The procedures for these old plot locations were different from those for the new plots. Old plots were classed as "undisturbed" or "disturbed" in the aerial photo phase of the sampling process. All disturbed plots and a one-third sample of the undisturbed plots were remeasured to obtain estimates of current condition and changes since the last inventory. All trees measured on these plots in 1977 were remeasured or otherwise accounted for, and all new trees were identified and measured.

All sample plots that were forested at the time of the 1977 inventory and determined to be undisturbed until this inventory were projected to the current time using STEMS. This procedure gives projected estimates of current volume and growth for these undisturbed plots. The comparison of the projected and observed values on the one-third sample of the undisturbed forest plots that were remeasured provided local calibration data to adjust the projected values of the undisturbed plots that were not remeasured. The adjustment procedure is a modified version of the method described by Smith".

The old sample plots that were not forested in 1977 and were determined to be undisturbed until the current inventory (no evidence of conversion to another land use) were also subsampled (field checked) at the one-third rate. Any changes in land use to forest detected on these plots were used to adjust the two-thirds sample of these plots not field checked. The field check of these points in the Prairie Unit indicated that no adjustment was necessary.

\footnotetext{
${ }^{4}$ Smith. W. Brad. 1983. Adjusting STEMS regional growth models to improve local predictions. Res. Note NC-297. St. Paul, MN: U.S. Department of Agriculture, Forest Service, North Central Forest Experiment Station. 5 p.
} 
The undisturbed plots that were not remeasured play a crucial role in the new survey design. These plots, after careful examination comparing past and current aerial photography, were determined to be undisturbed and had conditions that could be simulated by STEMS. The STEMS growth model was used to "grow" the old plot and tree data to produce an estimate of current data. Thus, these plots were treated as ground plots, even though they were never visited. The plot record for each modeled plot was sent to the field for verification of current ownership information.

All old plots classified as disturbed were sent to the field for remeasurement to assess and verify changes since the last inventory. Disturbance refers to any change on a plot that can be detected on aerial photos and that the STEMS growth processor cannot predict, such as catastrophic mortality, cutting, seedling stands, and land use change.

The estimation procedure for computing statistics from this sampling design was more complicated than the simple two-phase estimation procedure used in the past. In fact, this procedure yielded two independent samples, one coming from the new photo points and the other coming from the old photo points that are remeasured or modeled. The following tabulation summarizes the distribution of all ground plots for the new inventory design by type of plot:

\section{Area estimates}

Area estimates were made using two-phase estimation methods. In this type of estimation, a preliminary estimate of area by land use is made from the aerial photographs (Phase 1) and corrected by the plot measurements (Phase 2). A complete description of this estimation method is presented by Loetsch and Haller $(1964)^{5}$.

\section{Volume estimates}

Estimates of volume per acre were made from the trees measured or modeled on the 10-point plots. Estimates of volume per acre were multiplied by the area estimates to obtain estimates of total volume. Net cubic foot and board foot volumes are based on the following modification of the method presented by Hahn $(1984)^{6}$ for use in the Lake States. The merchantable height equation was used in conjunction with Stone's equation to estimate gross volume. This estimate was then corrected by species for variation in bark and cull volume to yield an estimate of net volume.

${ }^{5}$ Loetsch, F.; Haller, K.E. 1964. Forest inventory, volume 1, Statistics of forest inventory and information from aerial photographs. BLV Verlagsgesellschaft Munch Basle Vienna. 436 p.

${ }^{6}$ Hahn, Jerold T. 1984. Tree volume and biomass equations for the Lake States. Res. Pap. NC-250. St. Paul, MN: U.S. Department of Agriculture, Forest Service, North Central Forest Experiment Station. $10 \mathrm{p}$.

\begin{tabular}{lrrrr}
\hline Ground land use class & $\begin{array}{c}\text { Old plots } \\
\text { remeasured }\end{array}$ & $\begin{array}{c}\text { Old plots } \\
\text { updated }\end{array}$ & $\begin{array}{r}\text { New } \\
\text { plots }\end{array}$ & $\begin{array}{r}\text { Total } \\
\text { plots }\end{array}$ \\
\hline Timberland & 307 & 116 & 82 & 505 \\
Reserved forest land & 1 & 10 & - & 11 \\
Other forest land & 1 & 1 & 2 & 4 \\
Nonforest with trees & 87 & - & 15 & 102 \\
Nonforest without trees & 4,467 & 8,750 & 2,357 & 15,574 \\
Water & 90 & 166 & 80 & 336 \\
$\quad$ Total & 4,953 & 9,043 & 2,536 & 16,532 \\
\hline
\end{tabular}


The Forest Service reports all board foot volume in International 1/4-inch rule. In Minnesota, the Scribner log rule is commonly used. Scribner log rule conversion factors were derived from full tree measurements taken throughout the Lake States (Michigan, Wisconsin, and Minnesota) and an equation developed by Wiant and Castenaeda (1977) ${ }^{7}$. The factors (multipliers) used here to convert board foot International volumes to the Scribner rule are shown in the following tabulation:

$\begin{array}{ccc}\begin{array}{c}\text { D.b.h. } \\ \text { (inches) }\end{array} & \begin{array}{l}\text { Scribner rule conversion factor } \\ \text { Softwoods }\end{array} & \begin{array}{c}\text { Hardwoods } \\ \text { H.0-10.9 }\end{array} \\ 11.0-12.9 & .7830 & - \\ 13.0-14.9 & .8287 & 0.8317 \\ 15.0-16.9 & .8577 & .8611 \\ 17.0-18.9 & .8784 & .8827 \\ 19.0-20.9 & .8945 & .8999 \\ 21.0-22.9 & .9079 & .9132 \\ 23.0-24.9 & .9240 & .9239 \\ 25.0-26.9 & .9299 & .9325 \\ 27.0-28.9 & .9321 & .9396 \\ 29.0+ & .9357 & .9454 \\ & & .9544\end{array}$

\section{Growth and mortality estimates}

On remeasured plots, estimates of growth and mortality per acre come from the remeasured diameters of trees and from observation of trees that died between inventories. Growth, reported as the average net annual growth between the two inventories (1977 and 1990), is computed from data on remeasurement plots and modeled plots using methods presented by VanDeusen et al. $(1986)^{8}$. Mortality is also average net annual for the remeasurement period. On new plots, where trees were not remeasured, estimates of growth and mortality were obtained by using

\footnotetext{
${ }^{7}$ Wiant, Harry V., Jr.; Castenaeda, Froylan. 1977. Mesavage and Girard's volume tables formulated. BLM4. Denver, CO: U.S. Department of Interior, Bureau of Land Management, Denver Service Center: 1-4.

${ }^{8}$ VanDeusen, P.C.; Dell, T.R.; Thomas, C.E. 1986. Volume growth estimation from permanent horizontal points. Forest Science. 32: 415-422.
}

STEMS to project the growth and mortality of trees for 1 year. Growth and mortality estimates for old undisturbed plots that were updated were derived in the same manner as those for remeasured plots. The STEMS growth model was adjusted by Survey Unit to meet local conditions, using data from the undisturbed remeasurement plots. As with volume, total growth and mortality estimates were obtained by multiplying the per acre estimates by area estimates. Current annual growth for 1989 was computed by using the adjusted STEMS model to grow all current inventory plots for 1 year.

\section{Average annual removals estimates}

Average annual growing-stock and sawtimber removals ( 1977 to 1989 ) were estimated only from the remeasured plots; new plots were not used to estimate removals. These estimates are obtained from trees measured in the last survey and cut or otherwise removed from the timberland base. Because remeasurement plots make up about one-half of the total ground plots. average annual removals estimates have greater sampling errors than volume and growth estimates.

\section{COMPARING MINNESOTA'S FIFTH INVEN- TORY WITH THE FOURTH INVENTORY}

The following paragraphs highlight some of the procedural changes since the last inventory to assist the reader in analyzing data from this report:

A new volume estimation procedure was developed for the Lake States (see Survey Procedures section), and this procedure was used to compute the 1989 volumes and to recompute the 1977 volume for growth calculations. Although the adjustment will differ by Survey Unit and species, the recomputed 1977 growing-stock and board foot volumes will generally be greater than those shown in the 1977 report. 
Past surveys used only growing-stock trees to determine stand-size class. Current survey procedures require that stand-size class be determined on the basis of all live trees. Therefore, direct comparisons of current inventory data to old inventory data by stand-size class may be misleading.

The basic building block for estimating forest area and timber volume has been changed from the Survey Unit to the county. ${ }^{9}$ In the past, the statistics were developed at the Unit level and prorated back to the county on the basis of photo-interpretation plots. Direct development of county-level data helps users interested in more precise local data, but can make the outcome of comparisons with past estimates uncertain.

\section{TREE GRADE}

On approximately one-third of the sample plots in the Prairie and Central Hardwood Units of Minnesota, all sawtimber sample trees were graded for quality and assigned a tree grade. Tree grades are based on the classification of external characteristics as indicators of quality. The volume yield by tree grade for this sample was used to distribute the volume of the ungraded sample trees by species group.

\footnotetext{
${ }^{9}$ Counties where timberland area is small less than 35,000 acres) have been grouped to provide reporting areas with sampling errors lower than \pm 10 percent.

${ }^{10}$ Hanks, Leland F. 1976. Hardwood tree grades for factory lumber. Res. Pap. NE-333. Broomall, PA: U.S. Department of Agriculture, Forest Service, Northeastern Forest Experiment Station. 81 .
}

Hardwood sawtimber trees were graded according to "Hardwood tree grades for factory lumber". ${ }^{10}$ The best 12 -foot section of the lowest 16-foot hardwood log, or the best 12-foot upper section if the butt log did not meet minimum log-grade standards, was used for grading. Hardwood sawtimber trees that did not meet minimum tree grade specifications for grades 1 through 3 were assigned grade 4 according to Forest Service standard specifications for hardwood construction logs described in "A guide to hardwood log grading."11

Red pine and jack pine sawtimber trees were graded based on specifications described in "Forest Service log grades for southern pines." 12 White pine and other softwood sawtimber trees were graded according to specifications described in the circular "Log grades" ${ }^{13}$ from the University of Wisconsin. For all softwoods, the first merchantable 16 -foot log or shorter lengths down to 12 feet were used for grading.

\footnotetext{
11 Rast, Everette D.; Sonderman, David L.; Gammon, Glenn L. 1973. A guide to hardwood log grading. Gen. Tech. Rep. NE-1. Upper Darby. PA: U.S. Department of Agriculture, Forest Service, Northeastern Forest Experiment Station. 31 p.

12 Campbell, Robert A. 1964. Forest Service log grades for southern pine. Res. Pap. SE-11. Asheville, NC: U.S. Department of Agriculture, Forest Service, Southeastern Forest Experiment Station. 17 p.

13 Peterson, Ted. 1965. Log grades. Spec. Circ. 60. Madison, WI: University of Wisconsin, Extension Service, College of Agriculture. 4 p.
} 
Hardwood Tree Grades for Factory Lumber

\begin{tabular}{|c|c|c|c|}
\hline Grade factor & $\begin{array}{c}\text { Tree grade } \\
1 \\
\end{array}$ & $\begin{array}{c}\text { Tree grade } \\
2 \\
\end{array}$ & $\begin{array}{c}\text { Tree grade } \\
3 \\
\end{array}$ \\
\hline Length of grading zone (feet) & Butt 16 & Butt 16 & Butt 16 \\
\hline Length of grading section a (feet) & Best 12 & Best 12 & Best 12 \\
\hline D.b.h., minimum (inches) & $16^{\mathrm{b}}$ & 13 & 11 \\
\hline $\begin{array}{l}\text { Diameter, minimum inside bark at top of } \\
\text { grading section (inches) }\end{array}$ & $13^{\mathrm{b}} \quad 16 \quad 20$ & $11 \mathrm{C} \quad 12$ & 8 \\
\hline $\begin{array}{l}\text { Clear cuttings (on the three best faces) } \\
\text { Length, minimum (feet) }\end{array}$ & $7 \quad 5$ & 3 & 2 \\
\hline Number on face (maximum) & 2 & 2 & e \\
\hline Yield in face length (minimum) & $5 / 6$ & $4 / 6$ & $3 / 6$ \\
\hline $\begin{array}{l}\text { Cull deduction (including crook and } \\
\text { sweep, but excluding shake) } \\
\text { maximum within grading section } \\
\text { (percent) }\end{array}$ & 9 & $9^{f}$ & 50 \\
\hline
\end{tabular}

a Whenever a 14- or 16-foot section of the butt 16-foot log is better than the best 12-foot section, the grade of the longer section will become the grade of the tree. This longer section, when used, is the basis for determining the grading factors such as diameter and cull deduction.

$b$ In basswood and ash, d.i.b. at top of grading section must be 12 inches and d.b.h. must be 15 inches.

c Grade 2 trees can be 10 inches d.i.b. at top of grading section if otherwise meeting surface requirements for small grade 1's.

d A clear cutting is a portion of a face free of defects, extending the width of the face. A face is one-fourth of the surface of the grading section as divided lengthwise.

$e$ Unlimited.

$f$ Fifteen percent crook and sweep or 40 percent total cull deduction are permitted in grade 2, if size and surface of grading section qualify as grade 1. If rot shortens the required clear cuttings to the extent of dropping the butt log to grade 2 , do not drop the tree's grade to 3 unless the cull deduction for rot is greater than 40 percent. 


\section{Forest Service Standard Specifications for Hardwood Construction Logs (tie and timber logs) 1}

\begin{tabular}{ll}
\hline Position in tree & Butts and uppers \\
\hline Min. diameter. smallend & 8 inches + \\
\hline Min. length without trim & 8 feet \\
\hline Clearaltings & No requirements \\
Sweep allowance & $\begin{array}{l}\text { One-fourth of the diameter at the small end for } \\
\text { each } 8 \text { feet of length. }\end{array}$ \\
\hline
\end{tabular}

Sound surface defects:

Single knots

Any number, if no one knot has an average diameter above the callus in excess of one-third of the log diameter at point of occurrence.

Whorled knots

Any number, if the sum of knot diameters above the callus does not exceed one-third of the log diameter at point of occurrence.

Holes

Any number, provided none has a diameter over one-third of the log diameter at point of occurrence and none extends more than 3 inches into included timber ${ }^{2}$.

Unsound surface defects :

Same requirements as for sound defects if they extend into included timber. No limit if they do not.

\footnotetext{
${ }^{1}$ These specifications are minimum for the class. If, from a group of logs, factory logs are selected first, thus leaving only nonfactory logs from which to select construction logs, then the quality range of the construction logs so selected is limited, and the class may be considered a grade. If selection for construction logs is given first priority, it may be necessary to subdivide the class into grades.

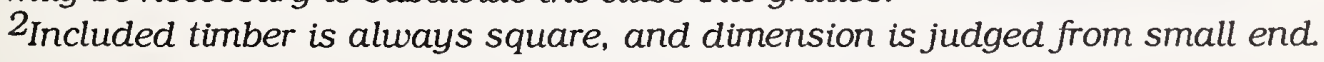




\section{Tree Grades for Eastern White Pine}

\begin{tabular}{|c|c|c|c|c|c|c|}
\hline $\begin{array}{l}\text { Log } \\
\text { grade }\end{array}$ & \multicolumn{2}{|c|}{$\begin{array}{l}\text { Minimum size }{ }^{1} \\
\text { Diameter Length }\end{array}$} & $\begin{array}{l}\text { Sweep } \\
\text { or crook } \\
\text { allowance }\end{array}$ & $\begin{array}{l}\text { Total cull } \\
\text { allowance } \\
\text { including } \\
\text { sweep }\end{array}$ & $\begin{array}{l}\text { Maximum } \\
\text { weevil } \\
\text { iniury }\end{array}$ & \multirow[t]{2}{*}{$\begin{array}{l}\text { Allowable knot size (inches) }{ }^{2} \\
\text { on three best faces or } \\
\text { minimum clearness on } \\
\text { fourfaces } \\
\text { (Inches) }\end{array}$} \\
\hline & (Inches) & eet $) \quad(P$ & cent) (Perc & nt) (Numb & & \\
\hline \multirow[t]{2}{*}{1} & $12 \& 13$ & $8-16$ & 20 & 50 & 0 & Four faces clear full length \\
\hline & $14+$ & $10-16$ & 20 & 50 & 0 & $\begin{array}{l}\text { Two faces clear full length, } \\
\text { or four faces clear } 50 \text { percent } \\
\text { length }(6 \text { feet min. length })^{3}\end{array}$ \\
\hline \multirow[t]{2}{*}{2} & $6+$ & $8-16$ & 30 & 50 & 0 & $\begin{array}{l}\text { Sound knots } 1 . e^{4} \text { D/6 and less } \\
\text { than } 3 \text { inches } 5\end{array}$ \\
\hline & & & & & & $\begin{array}{l}\text { Unsound knots: I.e. } 1-1 / 2 \text { inches and } \\
\text { for: butt, logs l.e. } D / 12 \text { upper } \\
\text { logs I.e. } D / 10 \text {, or four faces } \\
\text { clear } 50 \text { percent of length }\end{array}$ \\
\hline \multirow[t]{2}{*}{3} & $6+$ & $8-16$ & 40 & 50 & $\begin{array}{l}\text { 8-foot logs: } \\
1 \text { weevil }\end{array}$ & $\begin{array}{l}\text { Sound knots I.e.D/3 and } \\
\text { less than } 5 \text { inches }\end{array}$ \\
\hline & & & & & $\begin{array}{l}\text { 10-foot+ logs: } \\
2 \text { weevils }\end{array}$ & $\begin{array}{l}\text { Unsound knots l.e. D/6 and } \\
\text { less than } 2-1 / 2 \text { inches }\end{array}$ \\
\hline 4 & $6+$ & $8-16$ & 50 & 50 & No limit & No limit \\
\hline
\end{tabular}

$1_{\text {Plus trim. }}$

2 Disregard all knots less than 1/2-inch diameter in all grades.

${ }^{3}$ The sum of the diameter of sound knots plus twice the sum of the diameter of unsound knots (in inches) is less than or equal to half of the diameter of the log (inches).

4.e. means less than or equal to.

${ }^{5} \mathrm{D}$ means d.i.b. of $\log$ at location of knot. 
Grade 1: Trees with three or four clear faces on the 16-foot grading section. ${ }^{1}$

Grade 2: Trees with one or two clear faces on the 16-foot grading section.

Grade 3: Trees with no clear faces on the 16-foot grading section.

After the tentative grade is established from above, the tree will be reduced one grade for each of the following, except that no tree can be reduced below grade 3, provided the total scaling deductions for sweep and/or rot do not exceed two-thirds of the gross scale of the tree.

1. Sweep. Degrade any tentative grade 1 or 2 tree one grade if sweep in the lower 12 feet of grading sections amounts to 3 or more inches and equals or exceeds one-fourth of the diameter at breast height.

2. Heart rot. Degrade any tentative grade 1 or 2 tree one grade if conk, punk knots, massed hyphae, or other evidence of advanced heart rot is found anywhere on the main tree stem.

${ }^{1}$ A face is one-fourth of the circumference in width extending the full length of the grading section. Clear faces are those free of: knots measuring more than 1/2-inch in diameter, overgrown knots of any size, and holes more than 1/4-inch in diameter. Faces may be rotated to obtain the maximum number of clear on the grading section.

\section{TREE GRADES FOR ALL OTHER SOFTWOOD LOGS}

\section{Grade 1}

1. Trees must be 16 inches in diameter ${ }^{A}$ or larger, grading section 12 feet in length or longer, and with deduction for defect not over 30 percent of gross scale.

2. Trees must be at least 75 percent clear $^{B}$ on each of three faces.

3. All knots outside clear cutting must be sound and not more than 2-1/2 inches in size.

\section{Grade 2}

1. Trees must be 12 inches in diameter or larger, grading section 12 feet in length or longer, and with a net scale after deduction for defect of at least 50 percent of the gross scale deducted for defect.

2. Trees must be at least 50 percent clear on each of three faces or 75 percent clear on two faces.

\section{Grade 3}

1. Trees must be 6 inches in diameter or larger, grading section 12 feet in length or longer, and with a net scale after deduction for defect of at least 50 percent of the gross contents of the log.

Note: A) Diameters are diameter inside bark (d.i.b.) at small end of grading section.

B) Percent clear refers to percent clear in one continuous section. 


\section{METRIC EQUIVALENTS OF UNITS USED IN THIS REPORT}

1 acre $=4,046.86$ square meters or 0.405 hectare.

1,000 acres $=405$ hectares.

1 cubic foot $=0.0283$ cubic meter .

1 foot $=30.48$ centimeters or 0.3048 meter.

1 inch $=25.4$ millimeters, 2.54 centimeters, or 0.0254 meter.

1 pound $=0.454$ kilograms .

1 ton $=0.907$ metric tons.

\section{TREE SPECIES GROUPS IN MINNESOTA ${ }^{14}$}

\section{SOFTWOODS}

Eastern white pine Pinus strobus

Red pine Pinus resinosa

Jack pine Pinus banksiana

White spruce Picea glauca

Black spruce Picea mariana

Balsam fir Abies balsamea

Tamarack Larix laricina

Northern white-cedar Thuja occidentalis Other softwoods:

Eastern redcedar........... Juniperus virginiana Scotch pine ....................... Pinus sylvestris

\section{HARDWOODS}

Select white oak ${ }^{15}$

White oak Quercus alba

Bur oak Guercus macrocarpa

Select red oak ${ }^{15}$

Northern red oak

Other red oak ${ }^{15}$

Northern pin oak Quercus rubra

Black oak Hickory ${ }^{15}$

Shagbark hickory Carya ovata

Bitternut hickory Carya cordiformis

\footnotetext{
${ }^{14}$ The common and scientific names are based on:
} Little, Elbert L. 1981. Checklist of native and naturalized trees of the United States. Agric. Handb. 541. Washington, DC: U.S. Department of Agriculture, Forest Service. $385 p$.

${ }_{15}$ This species or species group is considered a hard hardwood, with an average specific gravity greater than or equal to 0.50 .
Basswood $^{16}$ Tilia americana

Yellow birch ${ }^{16}$

Hard maple ${ }^{15}$

Black maple Acer nigrum

Sugar maple Acer saccharum

Soft maple ${ }^{16}$

Red maple Acer rubrum

Silver maple Acer saccharinum

Elm

American elm ${ }^{16}$

Slippery elm ${ }^{16}$

Ulmus americana

Rock elm ${ }^{15}$

Ash ${ }^{15}$

White ash

Black ash Ulmus rubra

Green ash Fraxinus nigra

Cottonwood ${ }^{16}$

Black willow ${ }^{16}$

Hackberry ${ }^{16}$ Ulmus thomasii

Balsam poplar ${ }^{16}$

Aspen $^{16}$

Bigtooth aspen

Quaking aspen

Paper birch ${ }^{15}$...

Black cherry ${ }^{16}$

Black walnut ${ }^{15}$

Butternut ${ }^{16}$. Betula alleghaniensis

Other hardwoods

Boxelder ${ }^{16}$ negundo Black locust ${ }^{15}$..............Robinia pseudoacacia Red mulberry ${ }^{16}$.........................Morus rubra Honeylocust ${ }^{15}$............... Gleditsia triacanthos Northern catalpa ${ }^{15}$............. Catalpa speciosa Noncommercial species

Eastern hophornbeam ....... Ostrya virginiana Apple ..................................... Malus spp. American hornbeam ...... Carpinus caroliniana Wild plum Prunus spp. Hawthorn Crataegus spp.

${ }^{16}$ This species or species group is considered a soft hardwood, with an average specific gravity of less than 0.50 . 


\section{DEFINITION OF TERMS}

Average annual removals from growing stock.-The average net growing-stock volume in growing-stock trees removed annually for forest products (including roundwood products and logging residues) and for other uses (see Other removals). Average annual removals of growing stock are reported for a period of several years (1977 to 1989 in this report) and are based on information obtained from remeasurement plots (see Survey Procedures in Appendix).

\section{Average annual removals from sawtimber.-}

The average net board foot sawtimber volume of live sawtimber trees removed annually for forest products (including roundwood products and other uses [see Other removals]). Average annual removals of sawtimber are reported for a period of several years (1977 to 1989 in this report) and are based on information obtained from remeasurement plots (see Survey Procedures in Appendix).

Commercial species.-Tree species presently or prospectively suitable for industrial wood products. (Note: Excludes species of typically small size, poor form, or inferior quality such as hophornbeam, Osage-orange, and redbud.)

Commercial forest land.-(See Timberland).

Cord.- One standard cord is 128 cubic feet of stacked wood, including bark and air space. Cubic feet can be converted to standard cords by dividing by 79 .

County and municipal land.-Land owned by counties and local public agencies or municipalities, or land leased to these governmental units for 50 years or more.

Cull.-Portions of a tree that are unusable for industrial wood products because of rot, missing or dead material, or other defect.
Current annual growth of growing stock.The annual change in volume of sound wood in live sawtimber and poletimber trees and the total volume of trees entering these classes through ingrowth, less volume losses resulting from natural causes. Current growth is based on an estimate of the current annual increment of each growing-stock tree in the inventory.

Current annual growth of sawtimber.-The annual change in the volume of live sawtimber trees and the total volume of trees reaching sawtimber size, less volume losses resulting from natural causes. Current growth is based on an estimate of the current annual increment of each growing-stock tree in the inventory.

\section{Current annual removals from growing} stock.-The current net growing-stock volume in growing-stock trees removed annually for forest products (including roundwood products and logging residues) and for other uses (see Other removals). Current annual removals of growing stock are reported for a single year (1988 in this report) and are based on a survey of primary wood processing mills to determine removals for products and on information from remeasurement plots (see Survey Procedures in Appendix) to determine removals due to land use change.

\section{Current annual removals from sawtimber.-}

The current net board foot sawtimber volume of live sawtimber trees removed annually for forest products (including roundwood products and other uses [see Other removals]). Current annual removals of sawtimber are reported for a single year (1988 in this report) and are based on a survey of primary wood processing mills to determine removals for products and on information from remeasurement plots (see Survey Procedures in Appendix) to determine removals due to land use change. 
Diameter class.-A classification of trees based on diameter outside bark, measured at breast height (d.b.h.). Two-inch diameter classes are commonly used in Forest Inventory and Analysis, with the even inch the approximate midpoint for a class. For example, the 6-inch class includes trees 5.0 through 6.9 inches d.b.h.

Diameter at breast height (d.b.h.).-The outside bark diameter at 4.5 feet $(1.37 \mathrm{~m})$ above the forest floor on the uphill side of the tree. For determining breast height, the forest floor includes the duff layer that may be present, but does not include unincorporated woody debris that may rise above the ground line.

Farm.-Any place from which $\$ 1,000$ or more of agricultural products were produced and sold during the year.

Farmer-owned land.-Land owned by farm operators whether part of the farmstead or not. (Note: Excludes land leased by farm operators from nonfarm owners, such as railroad companies and States.)

\section{Forest land.-Land at least 16.7 percent} stocked by forest trees of any size, or formerly having had such tree cover, and not currently developed for nonforest use. (Note: Stocking is measured by comparing specified standards with basal area and/or number of trees, age or size, and spacing.) The minimum area for classification of forest land is 1 acre. Roadside, streamside, and shelterbelt strips of timber must have a crown width of at least 120 feet to qualify as forest land. Unimproved roads and trails, streams, or other bodies of water or clearings in forest areas shall be classed as forest if less than 120 feet wide. (See Tree, Land, Timberland, Reserved forest land, Other forest land, Stocking, and Water.)

Forest industry land.-Land owned by companies or individuals that operate a primary wood-using plant.
Forest type.-A classification of forest land based on the species forming a plurality of live tree stocking. Major forest types in the State are:

Jack pine.-Forests in which jack pine comprises a plurality of the stocking. (Common associates include eastern white pine, red pine, aspen, birch, and maple.)

Red pine.-Forests in which red pine comprises a plurality of the stocking. (Common associates include eastern white pine, jack pine, aspen, birch, and maple.)

White pine.-Forests in which eastern white pine comprises a plurality of the stocking. (Common associates include red pine, jack pine, aspen, birch, and maple.)

Balsam fir.-Forests in which balsam fir and white spruce comprise a plurality of stocking with balsam fir the most common. (Common associates include aspen, maple, birch, northern white-cedar, and tamarack.)

White spruce.-Forests in which white spruce and balsam fir comprise a plurality of the stocking with white spruce the most common. (Common associates include aspen. maple, birch, northern white-cedar, and tamarack.)

Black spruce.-Forests in which swamp conifers comprise a plurality of the stocking with black spruce the most common. (Common associates include tamarack and northern white-cedar.)

Northern white-cedar.-Forests in which swamp conifers comprise a plurality of the stocking with northern white-cedar the most common. (Common associates include tamarack and black spruce.)

Tamarack.-Forests in which swamp conifers comprise a plurality of the stocking with tamarack the most common. (Common associates include black spruce and northern white-cedar.)

Oak-hickory.-Forests in which northern red oak, white oak, bur oak, or hickories, singly or in combination, comprise a plurality of the stocking. (Common associates include jack pine, elm, and maple.)

Elm-ash-soft maple.-Forests in which lowland elm, ash, red maple, silver maple, and cottonwood, singly or in combination. comprise a plurality of the stocking. (Common 
associates include birches, spruce, and balsam fir.)

Maple-basswood.-Forests in which sugar maple, basswood, yellow birch, upland American elm, and red maple, singly or in combination, comprise a plurality of the stocking. (Common associates include white pine, elm, and basswood.)

Aspen.-Forests in which quaking aspen or bigtooth aspen, singly or in combination, comprise a plurality of the stocking. (Common associates include balsam poplar, balsam fir, and paper birch.)

Paper birch.-Forests in which paper birch comprises a plurality of the stocking. (Common associates include maple, aspen, and balsam fir.)

Balsam poplar.-Forests in which balsam poplar comprises a plurality of the stocking. (Common associates include aspen, elm, and ash.)

Growing-stock tree.-A live tree of commercial species that meets specified standards of size, quality, and merchantability. (Note: Excludes rough, rotten, and dead trees.)

Growing-stock volume.-Net volume in cubic feet of growing-stock trees 5.0 inches d.b.h. and over, from 1 foot above the ground to a minimum 4.0 inch top diameter outside bark of the central stem or to the point where the central stem breaks into limbs.

Hard hardwoods.- Hardwood species with an average specific gravity greater than 0.50 such as oaks, hard maple, hickories, and ash.

Hardwoods.-Dicotyledonous trees, usually broad-leaved and deciduous. (See Soft hardwoods and Hard hardwoods.)

Indian land.-Land held in trust by the United States for the tribes or individual Indians.

Land.-A. Bureau of the Census. Dry land and land temporarily or partly covered by water such as marshes, swamps, and river flood plains (omitting tidal flats below mean high tide); streams, sloughs, estuaries, and canals less than one-eighth of a statute mile wide; and lakes, reservoirs, and ponds less than 40 acres in area.
B. Forest Inventory and Analysis. The same as the Bureau of the Census, except minimum width of streams, etc., is 120 feet and minimum size of lakes, etc., is 1 acre.

Marsh.-Nonforest land that characteristically supports low, generally herbaceous or shrubby vegetation and that is intermittently covered with water.

Merchantable.-Refers to a pulpwood or sawlog section that meets pulpwood or saw-log specifications, respectively.

Miscellaneous Federal land.-Federal land other than National Forest and land administered by the Bureau of Land Management or Bureau of Indian Affairs.

Miscellaneous private land.-Privately owned land other than forest-industry and farmerowned land.

Mortality.-The volume of sound wood in growing-stock and sawtimber trees that die annually.

National Forest land.-Federal land that has been legally designated as National Forest or purchase units, and other land administered by the USDA Forest Service.

Net annual growth of growing stock.- The annual change in volume of sound wood in live sawtimber and poletimber trees and the total volume of trees entering these classes through ingrowth, less volume losses resulting from natural causes.

Net annual growth of sawtimber.-The annual change in the volume of live sawtimber trees and the total volume of trees reaching sawtimber size, less volume losses resulting from natural causes.

Net volume.-Gross volume less deductions for rot, sweep, or other defect affecting use for timber products.

Noncommercial species.-Tree species of typically small size, poor form, or inferior quality that normally do not develop into trees suitable for industrial wood products. 
Nonforest land.-Land that has never supported forests, and land formerly forested where use for timber management is precluded by development for other uses. (Note: Includes areas used for crops, improved pasture, residential areas, city parks, improved roads of any width and adjoining clearings, powerline clearings of any width. and 1 - to 40-acre areas of water classified by the Bureau of the Census as land. If intermingled in forest areas, unimproved roads and nonforest strips must be more than 120 feet wide and more than 1 acre in area to qualify as nonforest land.)

a. Nonforest land without trees.-Nonforest land with no live trees present.

b. Nonforest land with trees.-Nonforest land with one or more trees per acre at least 5 inches d.b.h.

Nonstocked land.-Forest land less than 16.7 percent stocked with all live trees.

Other forest land.-Forest land not capable of producing 20 cubic feet per acre per year of industrial wood crops under natural conditions and not associated with urban or rural development. These sites often contain tree species that are not currently utilized for industrial wood production or trees of poor form, small size, or inferior quality that are unfit for industrial products. Low productivity may be the result of adverse site conditions such as sterile soil, dry climate, poor drainage, high elevation, and rockiness. This land is not withdrawn from timber utilization.

Other removals.-Growing-stock trees removed but not utilized for products, or trees left standing but "removed" from the timberland classification by land use change. Examples are removals from cultural operations such as timber stand improvement work, land clearing, and changes in land use.

Poletimber stand.-(See Stand-size class.)

Poletimber tree.-A tree of commercial species at least 5.0 inches d.b.h. but smailer than sawtimber size.
Potential productivity class.-A classification of forest lands in terms of inherent capacity to grow crops of industrial wood. The class identifies the potential growth in merchantable cubic feet/acre/year at culmination of mean annual increment of fully stocked natural stands.

Reserved forest land.-Forest land withdrawn from timber utilization through statute, administrative regulation, designation, or exclusive use for Christmas tree production. as indicated by annual shearing.

Rotten tree.-A tree that does not meet regional merchantability standards because of excessive unsound cull. May include noncommercial tree species.

Rough tree.-A tree that does not meet regional merchantability standards because of excessive sound cull. May include noncommercial tree species.

Salvable dead tree.-A standing or down dead tree considered merchantable by regional standards.

Sapling.-A live tree 1.0 to 5.0 inches d.b.h.

Sapling-seedling stand.-(See Stand-size class.)

Saw log.-A log meeting minimum standards of diameter, length, and defect, including logs at least 8 feet long, sound and straight and with a minimum diameter outside bark (d.o.b.) for softwoods of 7.0 inches (9.0 inches for hardwoods) or other combinations of size and defect specified by regional standards.

Saw-log portion.- That part of the bole of sawtimber trees between the stump and the saw-log top.

Saw-log top.-The point on the bole of sawtimber trees above which a saw log cannot be produced. The minimum saw-log top is 7.0 inches d.o.b. for softwoods and 9.0 inches d.o.b. for hardwoods.

Sawtimber stand.-(See Stand-ske class.) 
Sawtimber tree.-A tree of commercial species containing at least a 12 -foot saw log or two noncontiguous saw logs 8 feet or longer, and meeting regional specifications for freedom from defect. Softwoods must be at least 9.0 inches d.b.h. Hardwoods must be at least 11.0 inches d.b.h.

Sawtimber volume.-Net volume of the saw-log portion of live sawtimber in board feet, International 1/4-inch rule (unless specified otherwise) from stump to a minimum 7 inches top diameter outside bark (d.o.b.) for softwoods and a minimum 9 inches top d.o.b. for hardwoods.

Seedling.-A live tree less than 1.0 inch d.b.h. that is expected to survive. Only softwood seedlings more than 6 inches tall and hardwood seedlings more than 1 foot tall are counted.

Short-log (rough tree).-Sawtimber-size trees of commercial species that contain at least one merchantable 8- to 11-foot saw log but not a 12 -foot saw $\log$.

Site index.-An expression of forest site quality based on the height of a free-growing dominant or codominant tree of a representative species in the forest type at age 50 .

Soft hardwoods.-Hardwood species with an average specific gravity less than 0.50 such as gum, yellow-poplar, cottonwood, red maple, basswood, and willow.

Softwoods.-Coniferous trees, usually evergreen, having needles or scale-like leaves.

Stand.-A group of trees on a minimum of 1 acre of forest land that is stocked by forest trees of any size.

Stand-size class.-A classification of stocked (see Stocking) forest land based on the size class of live trees on the area; that is, sawtimber, poletimber, or seedlings and saplings. a. Sawtimber stands.-Stands with half or more of live stocking in sawtimber or poletimber trees, and with sawtimber stocking at least equal to poletimber stocking.

b. Poletimber stands.-Stands with half or more live stocking in poletimber and/or sawtimber trees, and with poletimber stocking exceeding that of sawtimber.

c. Sapling-seedling stands.-Stands with more than half of the live stocking in saplings and/or seedlings.

State land.-Land owned by States or leased to them for 50 years or more.

Stocking.-The degree of occupancy of land by live trees, measured by basal area and/or the number of trees in a stand by size or age and spacing, compared to the basal area and/or number of trees required to fully utilize the growth potential of the land; that is, the stocking standard.

A stocking percent of 100 indicates full utilization of the site and is equivalent to 80 square feet of basal area per acre in trees 5.0 inches d.b.h. and larger. In a stand of trees less than 5 inches d.b.h., a stocking percent of 100 would indicate that the present number of trees is sufficient to produce 80 square feet of basal area per acre when the trees reach 5 inches d.b.h.

Stands are grouped into the following stocking classes:

Overstocked stands.-Stands in which stocking of live trees is 133 percent or more.

Fully stocked stands.-Stands in which stocking of live trees is from 100.0 to 132.9 percent.

Moderately stocked stands.-Stands in which stocking of live trees is from 60.0 to 99.9 percent.

Poorly stocked stands.-Stands in which stocking of live trees is from 16.7 to 59.9 percent.

Nonstocked areas. - Timberland on which stocking of live trees is less than 16.7 percent. 
Timberland.-Forest land that is producing or capable of producing in excess of 20 cubic feet per acre per year of industrial wood crops under natural conditions, that is not withdrawn from timber utilization, and that is not associated with urban or rural development. Currently inaccessible and inoperable areas are included.

Tree.-A woody plant usually having one or more perennial stems, a more or less definitely formed crown of foliage, and a height of at least 12 feet at maturity.

Tree grade.-A tree classification based on external characteristics of the butt log as an indicator of quality or value. Tree grades may be converted to lumber grade yields for individual species. (See Appendix for specific grading factors used.)

Tree size class.-A classification of trees based on diameter at breast height, including sawtimber trees, poletimber trees, saplings, and seedlings.

Upper stem portion.-That part of the bole of sawtimber trees above the saw log top to a minimum top diameter of 4.0 inches outside bark or to the point where the central stem breaks into limbs.

Water.-A. Bureau of the Census.-Permanent inland water surfaces, such as lakes, reservoirs, and ponds at least 40 acres in area; and streams, sloughs, estuaries, and canals at least one-eighth of a statute mile wide.

B. Noncensus.-Permanent inland water surfaces, such as lakes, reservoirs, and ponds from 1 to 39.9 acres in area; and streams, sloughs, estuaries, and canals from 120 feet to one-eighth of a statute mile wide.

Wooded strip.-An acre or more of natural continuous forest land that would otherwise meet survey standards for timberland except that it is less than 120 feet wide.

\section{Tables}

Table 1.-Area of land by county and major land-use class, Prairie Unit, Minnesota, 1990

Table 2.-Area of timberland by county and ownership class, Prairie Unit, Minnesota, 1990

Table 3.-Area of timberland by county and forest type, Prairie Unit, Minnesota, 1990

Table 4.-Area of timberland by county and stand-size class, Prairie Unit, Minnesota, 1990

Table 5.-Area of timberland by county and potential productivity class, Prairie Unit, Minnesota, 1990

Table 6.-Area of timberland by county and stocking class of growing-stock trees, Prairie Unit, Minnesota, 1990

Table 7.-Area of timberland by ownership class and stocking class of growingstock trees, Prairie Unit, Minnesota. 1990

Table 8.-Area of timberland by forest type and ownership class, Prairie Unit, Minnesota, 1990

Table 9.-Area of timberland by forest type and stand-size class, Prairie Unit, Minnesota, 1990

Table 10.-Number of all live trees on timberland by species group and diameter class, Prairie Unit, Minnesota, 1990

Table 11.-Number of growing-stock trees on timberland by species group and diameter class, Prairie Unit, Minnesota, 1990

Table 12.-Net volume of timber on timberland by class of timber and species group. Prairie Unit, Minnesota, 1990 
Table 13.-Net volume of growing-stock trees on timberland by species group and diameter class, Prairie Unit, Minnesota, 1990

Table 14.-Net volume of growing stock in the saw-log portion of sawtimber trees on timberland by species group and diameter class, Prairie Unit, Minnesota, 1990

Table 15.-Net volume of sawtimber trees on timberland by species group and diameter class, Prairie Unit, Minnesota, 1990

Table 16.-Net volume of growing stock and sawtimber on timberland by county and species group. Prairie Unit. Minnesota, 1990

Table 17.-Net volume of live trees and growing stock on timberland by ownership class and species group. Prairie Unit, Minnesota, 1990

Table 18.--Net volume of sawtimber trees on timberland by species group and butt log grade, Prairie Unit, Minnesota, 1990
Table 19.-Average net annual growth of growing siock and sawtimber on timberland by county and species group. Prairie Unit, Minnesota, 1977-1989

Table 20.-Average annual removals of growing stock and sawtimber on timberland by county and species group. Prairie Unit, Minnesota, 1977-1989

Table 21.-Average net annual growth, mortality, and removals of growing stock and sawtimber on timberland by species group, Prairie Unit, Minnesota, 1977-1989

Table 22.-Average net annual growth and average annual removals of growing stock on timberland by ownership class and species group, Prairie Unit, Minnesota, 1977-1989

Table 23.-Average net annual growth and average annual removals of sawtimber on timberland by ownership class and species group, Prairie Unit. Minnesota, 1977-1989

Table 24.-Current annual growth, mortality, and removals of growing stock and sawtimber on timberland by species group, Prairie Unit, Minnesota, 1989 
Table 1.--Area of land by county and major land-use class, Prairie Unit, Minnesota, 1990 (In thousand acres)

\begin{tabular}{|c|c|c|c|c|c|c|c|}
\hline \multirow[b]{2}{*}{ County and county group } & \multirow[b]{2}{*}{$\begin{array}{l}\text { Land } \\
\text { area }\end{array}$} & \multicolumn{6}{|c|}{ Forest land } \\
\hline & & $\begin{array}{c}\text { All } \\
\text { forest } \\
\text { land } \\
\end{array}$ & $\begin{array}{l}\text { Timber- } \\
\text { land }\end{array}$ & $\begin{array}{l}\text { Timberland } \\
\text { as a percent } \\
\text { of land area }\end{array}$ & $\begin{array}{l}\text { Other } \\
\text { forest } \\
\text { land }\end{array}$ & $\begin{array}{c}\text { Reserved } \\
\text { forest } \\
\text { land } \\
\end{array}$ & $\begin{array}{l}\text { Sampling } \\
\text { error for } \\
\text { timberland } \\
\text { (SE) }\end{array}$ \\
\hline & $\ldots . .$. & Thousand ac & .......... & Percent & ... Thou & d acres... & Percent \\
\hline Kittson & 706.6 & 56.2 & 54.0 & 7.6 & 0.8 & 1.3 & 8.1 \\
\hline Marshall & $1,127.4$ & 143.2 & 138.7 & 12.3 & 4.2 & 0.2 & 5.1 \\
\hline Polk & $1,267.1$ & 55.9 & 55.7 & 4.4 & 0.2 & .. & 8.0 \\
\hline Blue Earth & 479.4 & 26.2 & 25.5 & 5.3 & $\overline{0.1}$ & 0.6 & 11.9 \\
\hline Faribault & 452.0 & 6.8 & 6.5 & 1.4 & 0.3 & .. & 23.5 \\
\hline Blue Earth-Faribault total & 931.4 & 33.0 & 32.0 & 3.4 & 0.4 & 0.6 & 10.6 \\
\hline Clay & 669.3 & 13.4 & 12.9 & 1.9 & 0.3 & 0.2 & 16.7 \\
\hline Norman & 557.2 & 25.7 & 25.5 & 4.6 & 0.2 & -. & 11.9 \\
\hline Clay-Norman total & $1,226.5$ & 39.1 & 38.5 & 3.1 & 0.5 & 0.2 & 9.7 \\
\hline Dodge & 281.3 & 8.9 & 8.8 & 3.1 & $-\cdot$ & $-\cdot$ & 20.2 \\
\hline Freeborn & 447.2 & 4.2 & 4.2 & 0.9 & $\cdots$ & -. & 29.2 \\
\hline Mower & 457.4 & 3.4 & 3.0 & 0.7 & -. & 0.4 & 34.6 \\
\hline Steele & 274.7 & 9.0 & 8.7 & 3.2 & 0.1 & 0.2 & 20.3 \\
\hline Waseca & 270.2 & 10.1 & 10.0 & 3.7 & 0.1 & -. & 18.9 \\
\hline Eastern group total & 1.730 .8 & 35.6 & 34.7 & 2.0 & 0.2 & 0.6 & 10.2 \\
\hline Kandiyohi & 504.7 & 28.0 & 26.4 & 5.2 & 0.1 & 1.5 & 11.7 \\
\hline Meeker & 394.1 & 13.8 & 13.5 & 3.4 & 0.3 & $\ldots$ & 16.3 \\
\hline Kandiyohi-Meeker total & 898.8 & 41.8 & 39.9 & 4.4 & 0.4 & 1.5 & 9.5 \\
\hline McLeod & 318.3 & 8.8 & 8.7 & 2.7 & 0.1 & $-\cdot$ & 20.3 \\
\hline Nicollet & 283.5 & 22.0 & 21.4 & 7.5 & -. & 0.6 & 12.9 \\
\hline Renville & 633.8 & 16.0 & 15.9 & 2.5 & 0.2 & -- & 15.0 \\
\hline Sibley & 379.7 & 22.2 & 21.7 & 5.7 & 0.1 & 0.4 & 12.9 \\
\hline Northern group total & $1,615.3$ & 69.0 & 67.7 & 4.2 & 0.4 & 1.0 & 7.3 \\
\hline Penningion & 389.1 & 33.6 & 33.5 & 8.6 & 0.1 & -. & 10.3 \\
\hline Red Lake & 276.7 & 26.4 & 26.4 & 9.5 & 0.1 & -. & 11.7 \\
\hline Pennington-Red Lake total & 665.8 & 60.0 & 59.9 & 9.0 & 0.2 & 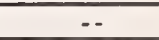 & 7.7 \\
\hline Brown & 385.4 & 15.6 & 14.9 & 3.9 & 0.1 & 0.6 & 15.5 \\
\hline Cottonwood & 404.8 & 4.2 & 4.1 & 1.0 & 0.1 & -. & 29.6 \\
\hline Jackson & 448.7 & 3.8 & 3.6 & 0.8 & 0.1 & 0.2 & 31.6 \\
\hline Martin & 450.1 & 3.0 & 3.0 & 0.7 & 0.1 & - & 34.6 \\
\hline Redwood & 564.0 & 9.8 & 9.7 & 1.7 & 0.1 & -. & 19.2 \\
\hline Watonwan & 278.9 & 5.6 & 5.6 & 2.0 & -. & .. & 25.3 \\
\hline Southern group total & $2,531.9$ & 42.0 & 40.9 & 1.6 & 0.5 & 0.8 & 9.4 \\
\hline Big Stone & 323.7 & 2.1 & 2.0 & 0.6 & 0.1 & $\cdots$ & 42.3 \\
\hline Chippewa & 377.3 & 7.3 & 7.2 & 1.9 & 0.1 & $\cdots$ & 22.3 \\
\hline Grant & 344.1 & 4.7 & 4.6 & 1.3 & 0.1 & -- & 27.9 \\
\hline Lac Qui Parle & 491.1 & 9.0 & 8.3 & 1.7 & 0.2 & 0.4 & 20.8 \\
\hline Lincoln & 338.5 & 2.8 & 2.8 & 0.8 & $\cdots$ & $\cdots$ & 35.8 \\
\hline Lyon & 457.2 & 10.0 & 9.3 & 2.0 & 0.1 & 0.6 & 19.6 \\
\hline Murray & 449.0 & 4.9 & 4.2 & 0.9 & 0.1 & 0.6 & 29.2 \\
\hline Nobles & 458.9 & 0.5 & 0.5 & 0.1 & .. & -- & 84.7 \\
\hline Pipestone & 303.4 & 0.6 & 0.6 & 0.2 & -- & -. & 77.3 \\
\hline Pope & 423.5 & 18.7 & 18.6 & 4.4 & 0.1 &.- & 13.9 \\
\hline Rock & 308.1 & 1.7 & 1.6 & 0.5 & 0.1 & - & 47.3 \\
\hline Stevens & 356.5 & 4.1 & 4.0 & 1.1 & 0.1 & $\cdots$ & 29.9 \\
\hline Swift & 477.2 & 5.3 & 5.3 & 1.1 & 0.1 & -. & 26.0 \\
\hline Traverse & 369.6 & 2.1 & 2.0 & 0.5 & 0.1 & . & 42.3 \\
\hline Wilkin & 479.9 & 3.4 & 3.4 & 0.7 & 0.1 & -. & 32.5 \\
\hline Yellow Medicine & 482.4 & 7.4 & 7.4 & 1.5 & -. & $\ldots$ & 22.0 \\
\hline Western group total & $6,440.4$ & 84.6 & 81.8 & 1.3 & 1.3 & 1.5 & 6.6 \\
\hline All counties & $19,142.1$ & 660.4 & 643.8 & 3.4 & 9.1 & 7.6 & 2.4 \\
\hline
\end{tabular}




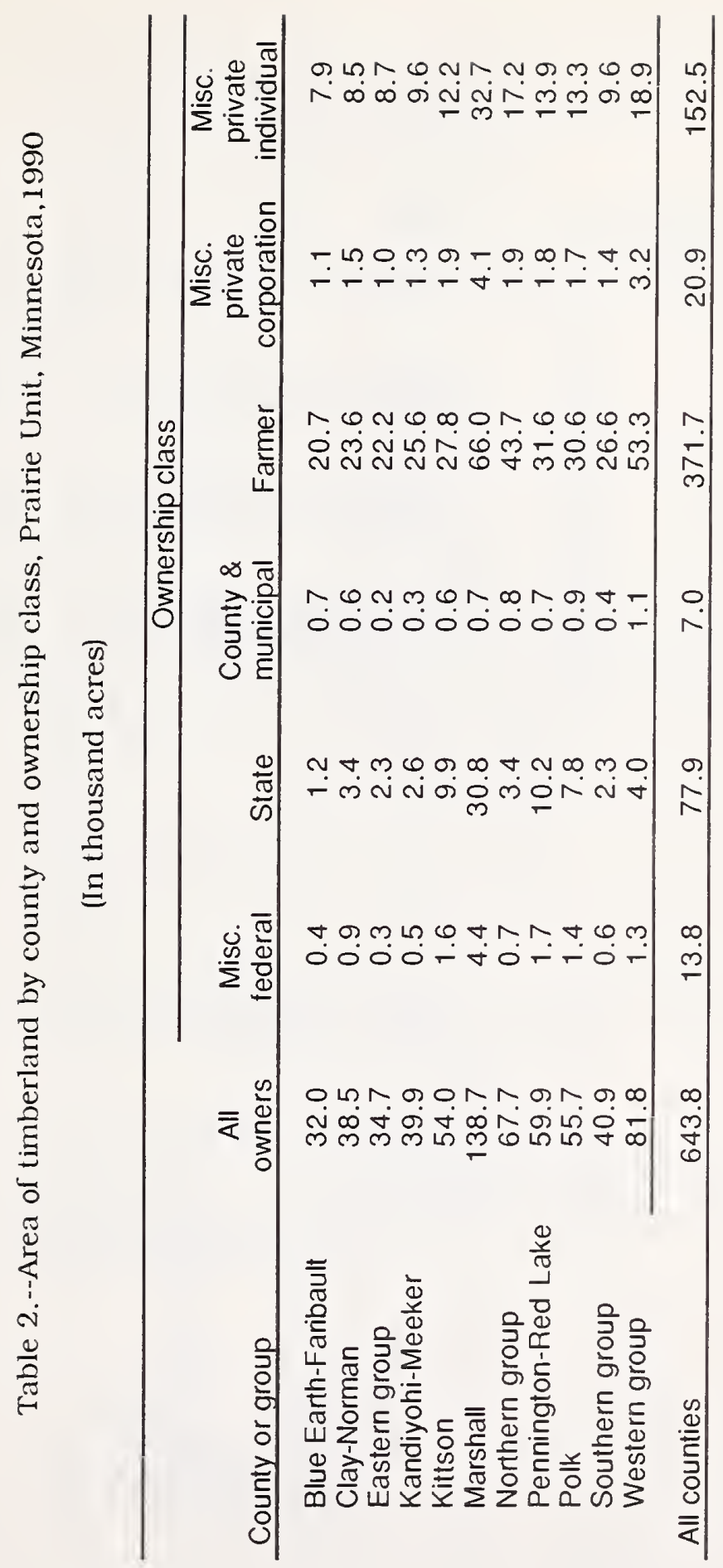




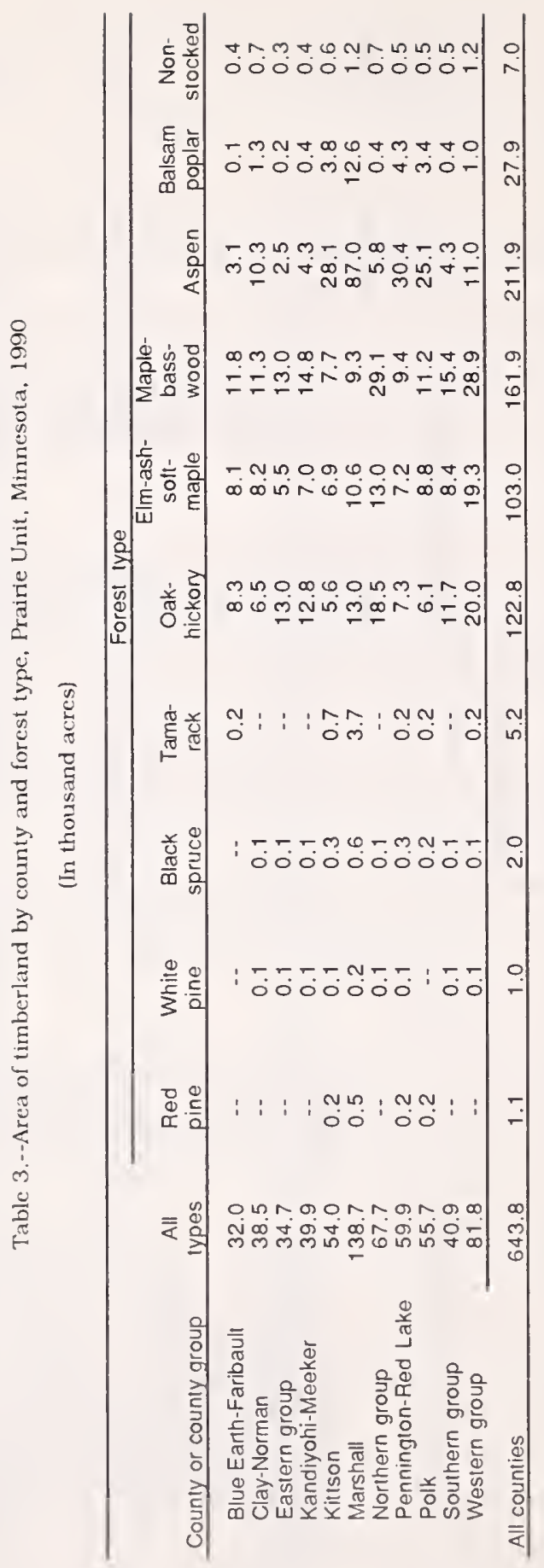


Table 4.--Area of timberland by county and stand-size class,

Prairie Unit, Minnesota, 1990

(In thousand acres)

\begin{tabular}{|c|c|c|c|c|c|}
\hline \multirow[b]{2}{*}{ County or county group } & \multirow[b]{2}{*}{$\begin{array}{c}\text { All } \\
\text { stands } \\
\end{array}$} & \multicolumn{4}{|c|}{ Stand-size class } \\
\hline & & Sawtimber & Poletimber & $\begin{array}{c}\text { Seedling \& } \\
\text { sapling }\end{array}$ & Nonstocked \\
\hline Blue Earth-Faribault & 32.0 & 22.8 & 4.4 & 4.4 & 0.4 \\
\hline Clay-Norman & 38.5 & 20.3 & 7.5 & 10.0 & 0.7 \\
\hline Eastern group & 34.7 & 25.5 & 3.5 & 5.4 & 0.3 \\
\hline Kandiyohi-Meeker & 39.9 & 27.7 & 4.4 & 7.4 & 0.4 \\
\hline Kittson & 54.0 & 16.4 & 17.3 & 19.7 & 0.6 \\
\hline Marshall & 138.7 & 26.9 & 51.7 & 58.9 & 1.2 \\
\hline Northern group & 67.7 & 49.3 & 7.4 & 10.3 & 0.7 \\
\hline Pennington-Red Lake & 59.9 & 20.1 & 20.0 & 19.3 & 0.5 \\
\hline Polk & 55.7 & 22.2 & 17.8 & 15.2 & 0.5 \\
\hline Southern group & 40.9 & 28.1 & 4.6 & 7.7 & 0.5 \\
\hline Western group & 81.8 & 53.3 & 10.9 & 16.4 & 1.2 \\
\hline All counties & 643.8 & 312.6 & 149.5 & 174.7 & 7.0 \\
\hline
\end{tabular}

Table 5.--Area of timberland by county and potential productivity class,

Prairie Unit, Minnesota, 1990

(In thousand acres)

\begin{tabular}{lcrrrrr}
\hline & All & \multicolumn{5}{c}{ Site class (cubic feet of growth per acre per year) } \\
\cline { 3 - 7 } County or county group & classes & $165+$ & $120-164$ & $85-119$ & $50-84$ & $20-49$ \\
\hline Blue Earth-Faribault & 32.0 & 0.3 & 0.7 & 4.7 & 9.8 & 16.5 \\
Clay-Norman & 38.5 & 0.3 & 0.5 & 5.1 & 14.5 & 18.1 \\
Eastern group & 34.7 & 0.5 & 0.5 & 5.0 & 8.5 & 20.2 \\
Kandiyohi-Meeker & 39.9 & 0.5 & 0.6 & 5.7 & 10.9 & 22.2 \\
Kittson & 54.0 & -- & 0.5 & 7.6 & 23.0 & 22.9 \\
Marshall & 138.7 & 0.3 & 0.3 & 20.6 & 60.7 & 56.8 \\
Northern group & 67.7 & 0.6 & 1.1 & 10.6 & 17.9 & 37.5 \\
Pennington-Red Lake & 59.9 & 0.1 & 0.5 & 8.3 & 25.1 & 25.9 \\
Polk & 55.7 & -- & 0.7 & 8.1 & 23.1 & 23.8 \\
Southern group & 40.9 & 0.5 & 0.7 & 5.7 & 12.0 & 22.0 \\
Western group & 81.8 & 0.9 & 1.4 & 11.0 & 27.1 & 41.4 \\
All counties & 643.8 & 4.0 & 7.5 & 92.4 & 232.6 & 307.3 \\
\hline
\end{tabular}


Table 6.--Area of timberland by county and stocking class of growing-stock trees ${ }^{1}$. Prairie Unit, Minnesota, 1990

(In thousand acres)

\begin{tabular}{lrrrrrr}
\hline & \multirow{2}{*}{\begin{tabular}{c} 
Sll \\
\cline { 3 - 6 } County or county group
\end{tabular}} & $\begin{array}{c}\text { Non- } \\
\text { classes }\end{array}$ & $\begin{array}{c}\text { Poorly } \\
\text { stocked }\end{array}$ & stocked & Moderately & growing-stock trees \\
stocked & Fully & Over- \\
stocked & stocked \\
\hline Blue Earth-Faribault & 32.0 & 1.0 & 10.3 & 16.6 & 3.8 & 0.3 \\
Clay-Norman & 38.5 & 1.3 & 11.5 & 17.9 & 5.7 & 2.1 \\
Eastern group & 34.7 & 1.4 & 10.2 & 17.8 & 4.2 & 1.1 \\
Kandiyohi-Meeker & 39.9 & 1.6 & 11.6 & 20.2 & 5.0 & 1.5 \\
Kittson & 54.0 & 1.7 & 15.6 & 20.7 & 10.6 & 5.4 \\
Marshall & 138.7 & 3.9 & 38.9 & 50.2 & 28.9 & 16.8 \\
Northern group & 67.7 & 2.5 & 19.2 & 35.1 & 8.1 & 2.8 \\
Pennington-Red Lake & 59.9 & 1.8 & 16.8 & 23.4 & 11.9 & 6.0 \\
Polk & 55.7 & 1.5 & 16.1 & 23.1 & 10.3 & 4.7 \\
Southern group & 40.9 & 1.6 & 12.1 & 20.9 & 5.0 & 1.3 \\
Western group & 81.8 & 2.8 & 25.0 & 41.7 & 10.0 & 2.3 \\
All counties & 643.8 & 21.0 & 186.9 & 287.0 & 103.3 & 44.2 \\
\hline
\end{tabular}

${ }^{1}$ This table is based on the stocking percent of growing-stock trees rather than that of all live trees. To use the definitions of stocking for this table, replace the term "all live" by "growing-stock."

Table 7.--Area of timberland by ownership class and stocking class of growing-stock trees ${ }^{1}$. Prairie Unit, Minnesota, 1990

(In thousand acres)

\begin{tabular}{|c|c|c|c|c|c|c|}
\hline \multirow[b]{2}{*}{ Ownership class } & \multirow[b]{2}{*}{$\begin{array}{c}\text { All } \\
\text { classes } \\
\end{array}$} & \multicolumn{5}{|c|}{ Stocking percent of growing-stock trees } \\
\hline & & $\begin{array}{c}\text { Non- } \\
\text { stocked }\end{array}$ & $\begin{array}{l}\text { Poorly } \\
\text { stocked }\end{array}$ & $\begin{array}{l}\text { Moderately } \\
\text { stocked }\end{array}$ & $\begin{array}{c}\text { Fully } \\
\text { stocked }\end{array}$ & $\begin{array}{c}\text { Over- } \\
\text { stocked }\end{array}$ \\
\hline Miscellaneous federal & 13.8 & 1.1 & 2.3 & 3.1 & 5.1 & 2.2 \\
\hline State & 77.9 & 4.4 & 21.8 & 17.7 & 17.4 & 16.6 \\
\hline County and municipal & 7.0 & -. & 4.6 & -- & 2.4 & -- \\
\hline Forest Industry & & -- & -- & -. & -. & -. \\
\hline Farmer & 371.7 & 12.6 & 106.8 & 181.7 & 53.6 & 17.0 \\
\hline $\begin{array}{l}\text { Miscellaneous } \\
\text { private corporation }\end{array}$ & 20.9 & 1.9 & 8.5 & 8.3 & 1.1 & 1.1 \\
\hline $\begin{array}{l}\text { Miscellaneous } \\
\text { private individual }\end{array}$ & 152.5 & 1.1 & 43.3 & 76.8 & 23.9 & 7.4 \\
\hline All owners & 643.8 & 21.1 & 187.3 & 287.6 & 103.5 & 44.3 \\
\hline
\end{tabular}

${ }^{1}$ This table is based on the stocking percent of growing-stock trees rather than that of all live trees. To use the definitions of stocking for this table, replace the term "all live" by "growing-stock." 


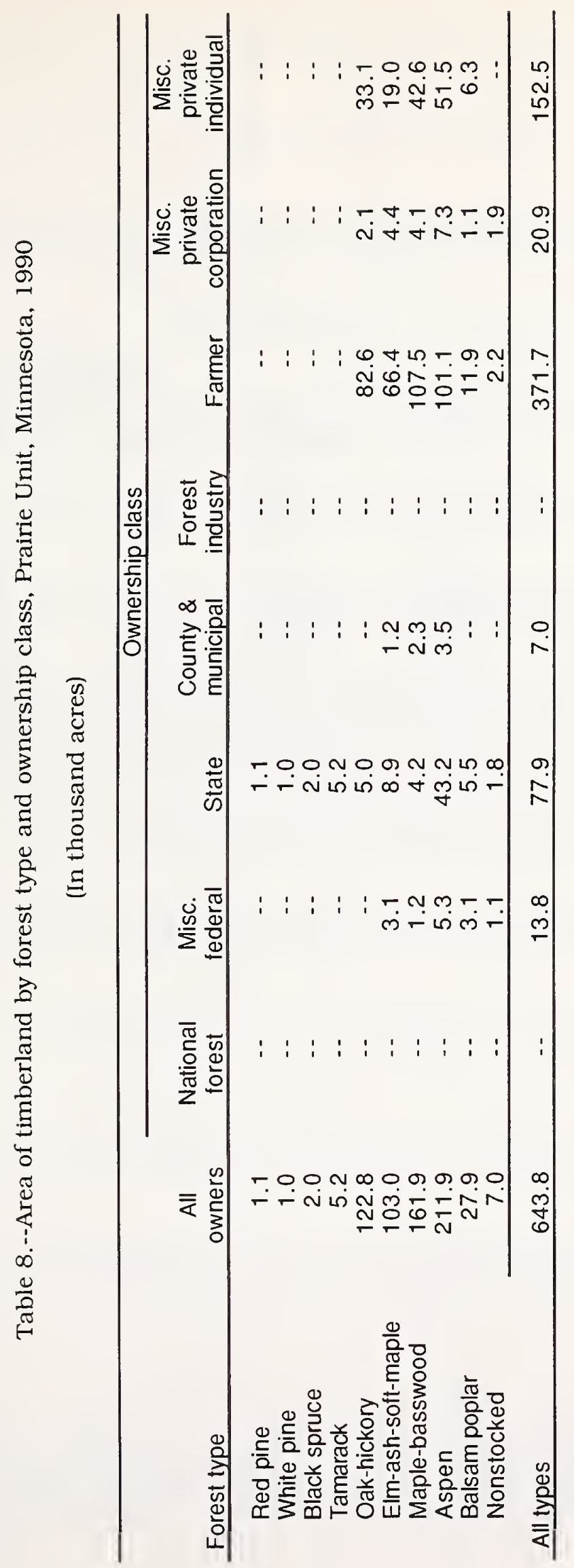


Table 9.--Area of timberland by forest type and stand-size class,

Prairie Unit, Minnesota, 1990

(In thousand acres)

\begin{tabular}{|c|c|c|c|c|c|}
\hline \multirow[b]{2}{*}{ Forest type } & \multirow[b]{2}{*}{$\begin{array}{c}\text { All } \\
\text { stands }\end{array}$} & \multicolumn{4}{|c|}{ Stand-size class } \\
\hline & & Sawtimber & Poletimber & $\begin{array}{c}\text { Seedling \& } \\
\text { sapling } \\
\end{array}$ & Nonstocked \\
\hline Red pine & 1.1 & 1.1 & -- & -- & -. \\
\hline White pine & 1.0 & 1.0 & - - & -- & -- \\
\hline Black spruce & 2.0 & -. & 1.1 & 0.9 & -- \\
\hline Tamarack & 5.2 & -- & 1.1 & 4.1 & - \\
\hline Oak-hickory & 122.8 & 98.5 & 8.8 & 15.5 & -. \\
\hline Elm-ash-soft-maple & 103.0 & 68.7 & 17.6 & 16.7 & -. \\
\hline Maple-basswood & 161.9 & 118.9 & 18.0 & 25.0 & -- \\
\hline Aspen & 211.9 & 24.4 & 85.6 & 101.9 & -- \\
\hline Balsam poplar & 27.9 & -- & 17.3 & 10.6 & -- \\
\hline Nonstocked & 7.0 & - & -- & -- & 7.0 \\
\hline All types & 643.8 & 312.6 & 149.5 & 174.7 & 7.0 \\
\hline
\end{tabular}




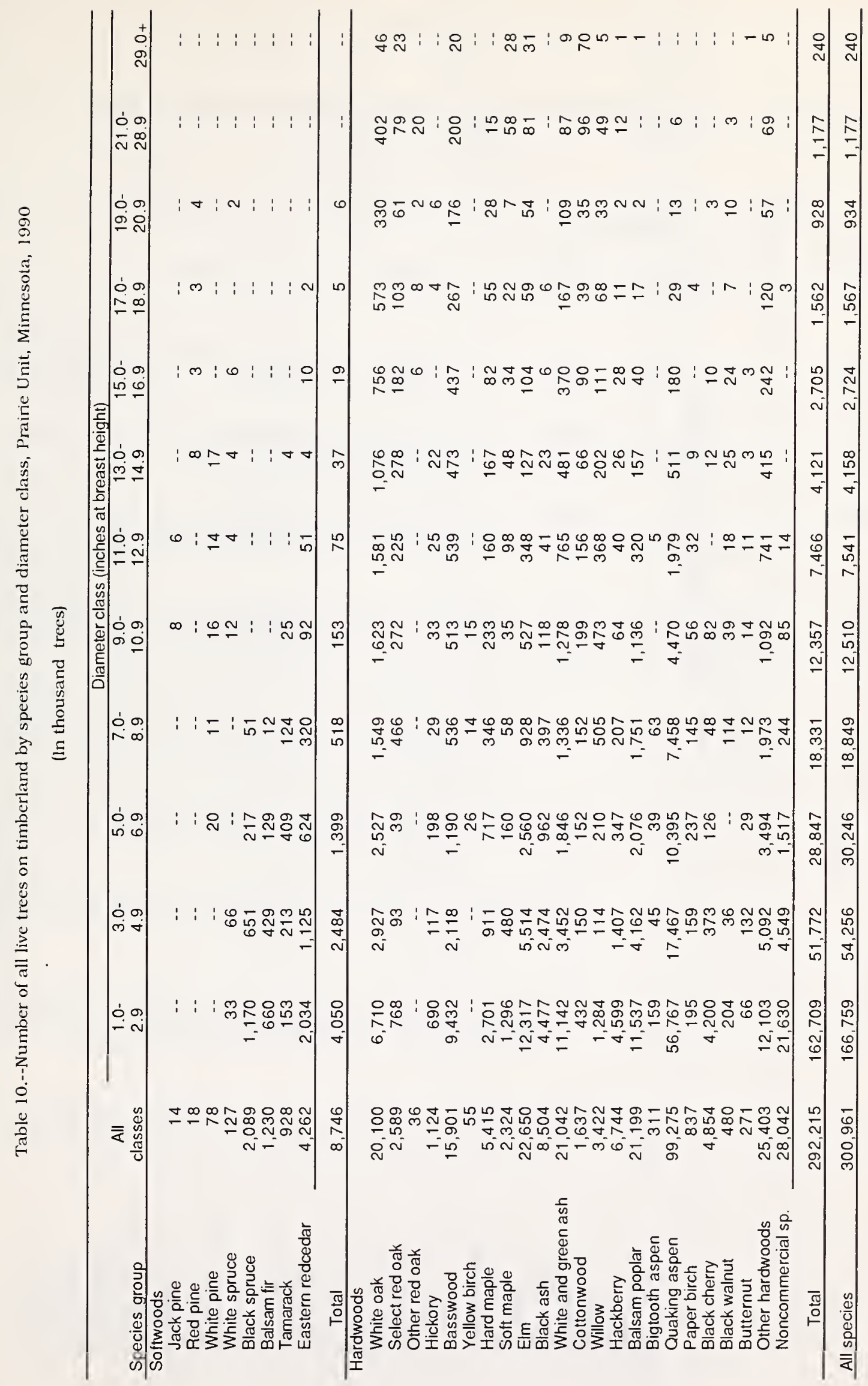




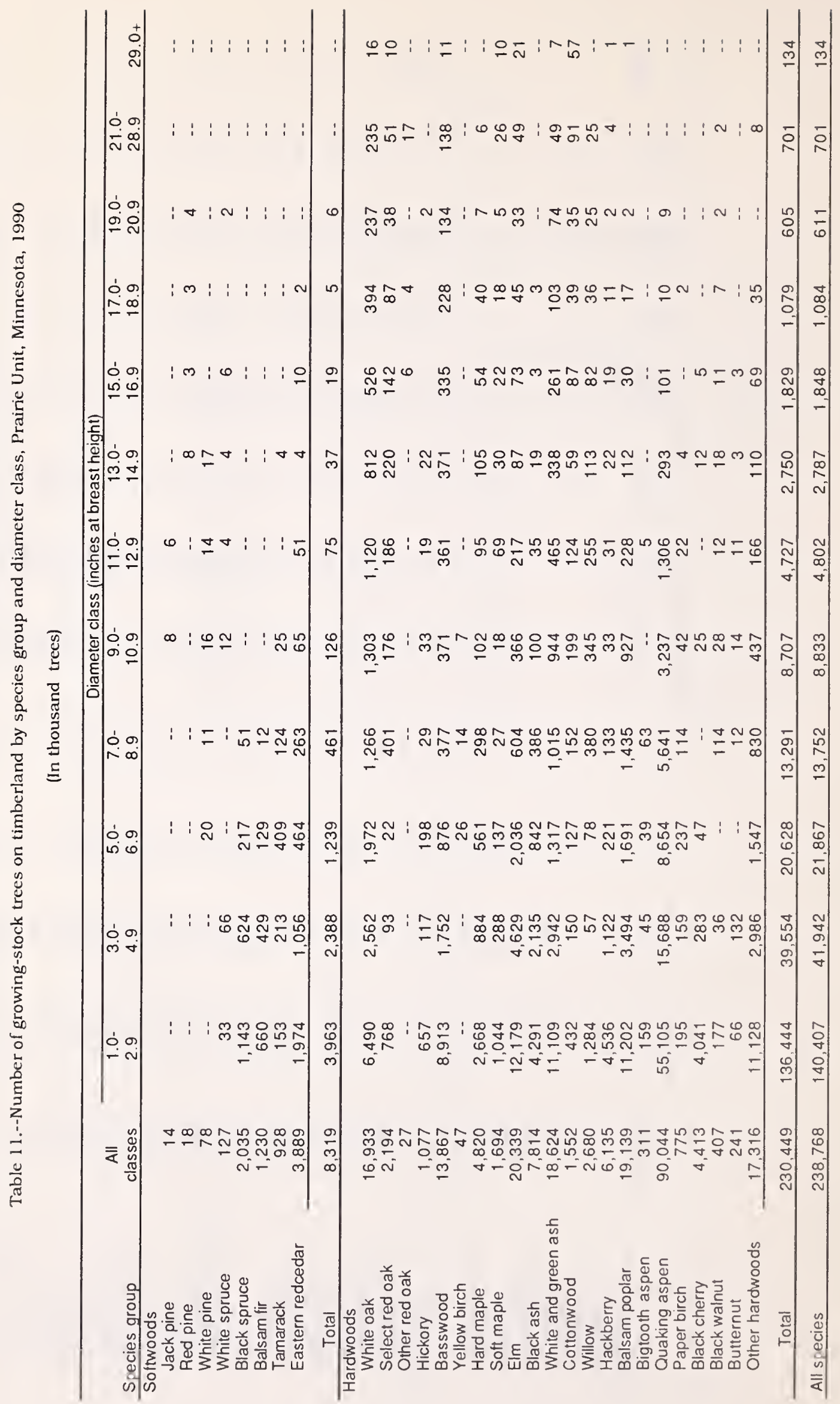


Table 12.--Net volume of timber on timberland by class of timber and species group, Prairie Unit, Minnesota, 1990

(In thousand cubic feet)

\begin{tabular}{|c|c|c|c|c|c|}
\hline \multirow[b]{2}{*}{ Class of timber } & \multirow[b]{2}{*}{$\begin{array}{c}\text { All } \\
\text { species }\end{array}$} & \multicolumn{4}{|c|}{ Species group } \\
\hline & & Pine & $\begin{array}{c}\text { Other } \\
\text { softwoods }\end{array}$ & $\begin{array}{c}\text { Soft } \\
\text { hardwoods }\end{array}$ & $\begin{array}{c}\text { Hard } \\
\text { hardwoods }\end{array}$ \\
\hline $\begin{array}{l}\text { Live trees } \\
\text { Growing-stock trees } \\
\text { Sawtimber }\end{array}$ & & & & & \\
\hline $\begin{array}{l}\text { Saw-log portion } \\
\text { Upper stem portion }\end{array}$ & $\begin{array}{r}254,742 \\
91,359 \\
\end{array}$ & $\begin{array}{r}1,370 \\
182 \\
\end{array}$ & $\begin{array}{r}2,731 \\
390 \\
\end{array}$ & $\begin{array}{r}121,772 \\
44,746 \\
\end{array}$ & $\begin{array}{r}128,869 \\
46,041 \\
\end{array}$ \\
\hline Total & 346,101 & 1,552 & 3,121 & 166,518 & 174,910 \\
\hline Poletimber & 219,273 & 92 & 6,101 & 144,727 & 68,353 \\
\hline All growing-stock trees & 565,374 & 1,644 & 9,222 & 311,245 & 243,263 \\
\hline $\begin{array}{l}\text { Cull trees } \\
\text { Short-log trees } \\
\text { Rough trees }\end{array}$ & 50,010 & -- & 115 & 17,023 & 32,872 \\
\hline $\begin{array}{l}\text { Sawtimber } \\
\text { Poletimber }\end{array}$ & $\begin{array}{l}74,854 \\
61,451 \\
\end{array}$ & $\begin{array}{ll}-- \\
-- \\
\end{array}$ & $\begin{array}{r}94 \\
520 \\
\end{array}$ & $\begin{array}{l}26,150 \\
31,660 \\
\end{array}$ & $\begin{array}{l}48,610 \\
29,271 \\
\end{array}$ \\
\hline Total & 136,305 & -- & 614 & 57,810 & 77,881 \\
\hline $\begin{array}{l}\text { Rotten trees } \\
\text { Sawtimber } \\
\text { Poletimber }\end{array}$ & $\begin{array}{r}17,961 \\
5,014 \\
\end{array}$ & $\begin{array}{ll}-\cdot \\
-- \\
\end{array}$ & $\begin{array}{ll}- \\
--\end{array}$ & $\begin{array}{l}9,718 \\
3,614 \\
\end{array}$ & $\begin{array}{l}8,243 \\
1,400 \\
\end{array}$ \\
\hline Total & 22,975 & -- & -- & 13,332 & 9,643 \\
\hline All cull trees & 209,290 & -- & 729 & 88,165 & 120,396 \\
\hline All live trees & 774,664 & 1,644 & 9,951 & 399,410 & 363.659 \\
\hline $\begin{array}{l}\text { Salvable dead trees } \\
\text { Sawtimber } \\
\text { Poletimber }\end{array}$ & $\begin{array}{l}26,797 \\
11,961 \\
\end{array}$ & $\begin{array}{ll}-- \\
-- \\
\end{array}$ & $\begin{array}{l}88 \\
69 \\
\end{array}$ & $\begin{array}{l}23,576 \\
10,332 \\
\end{array}$ & $\begin{array}{l}3,133 \\
1,560 \\
\end{array}$ \\
\hline Total & 38,758 & - & 157 & 33,908 & 4,693 \\
\hline All classes of timber & 813,422 & 1,644 & 10,108 & 433,318 & 368,352 \\
\hline
\end{tabular}




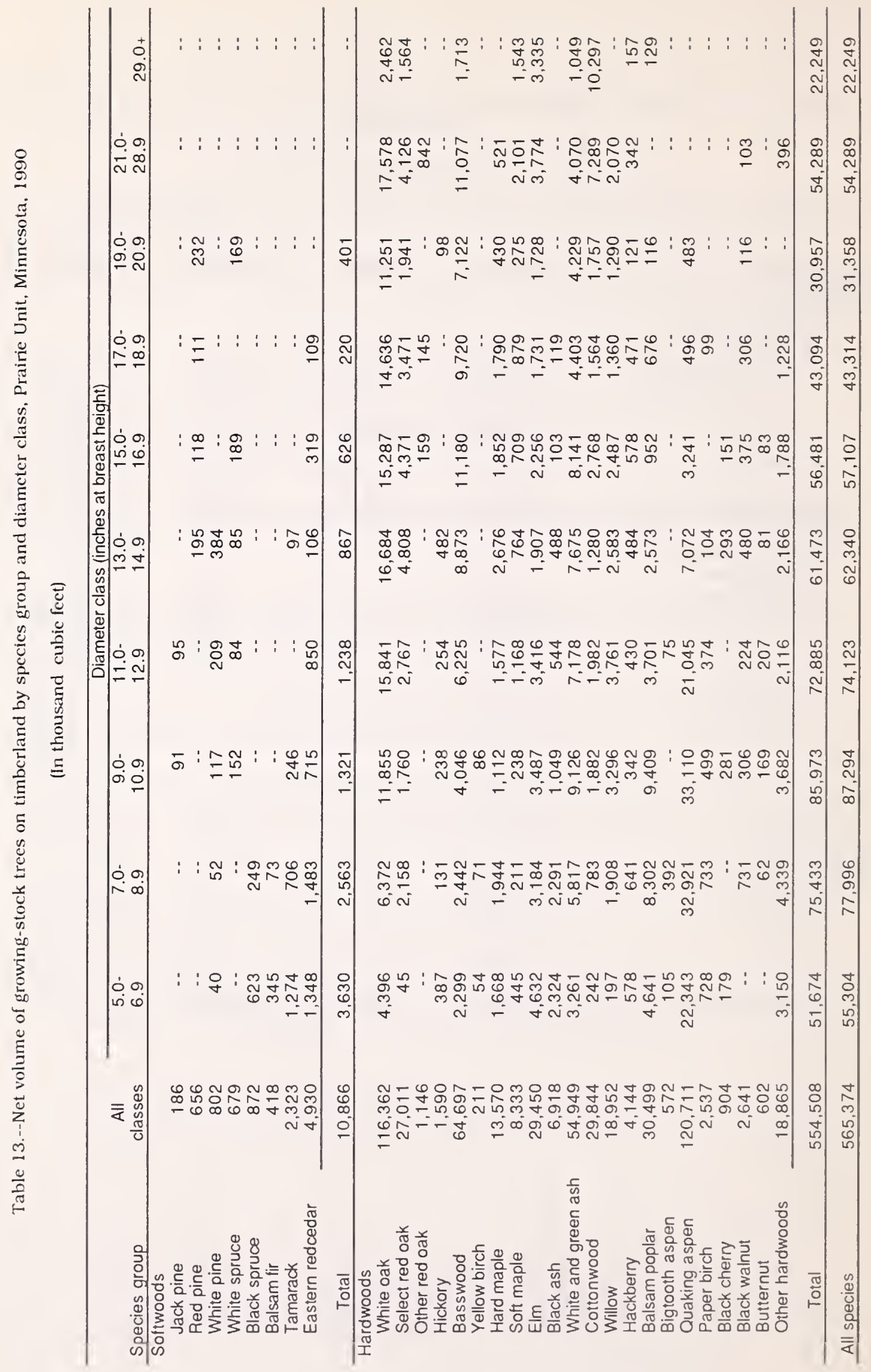




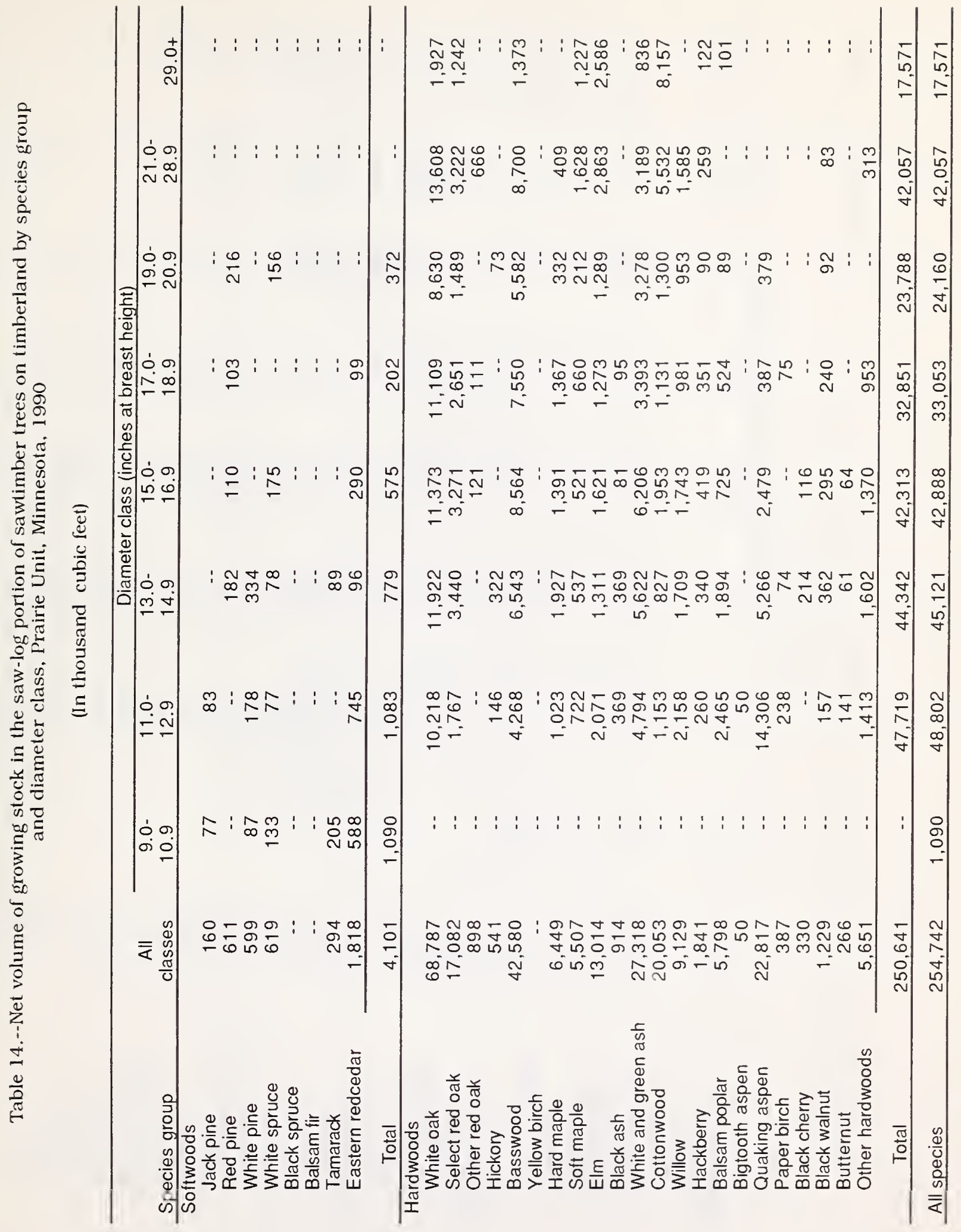




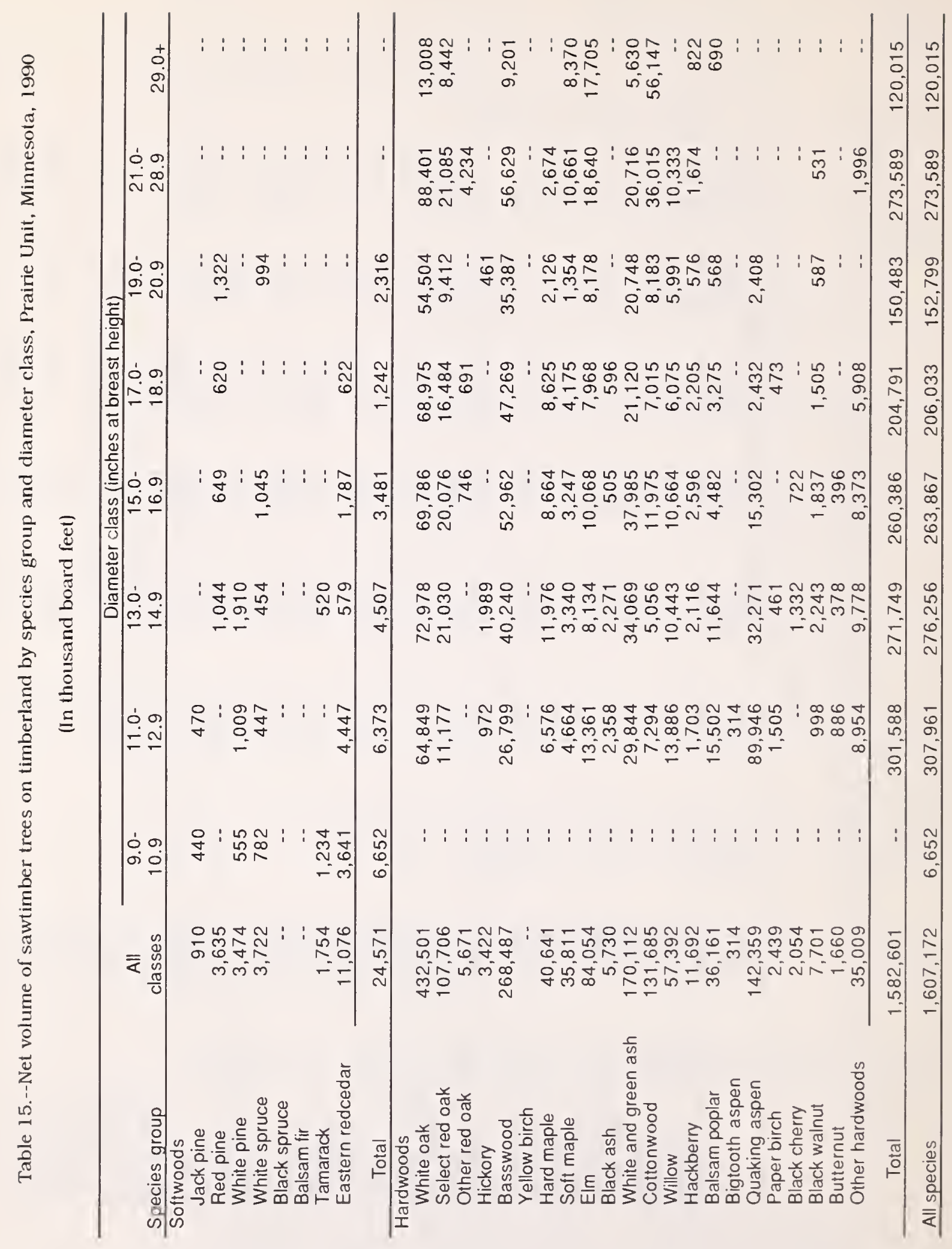




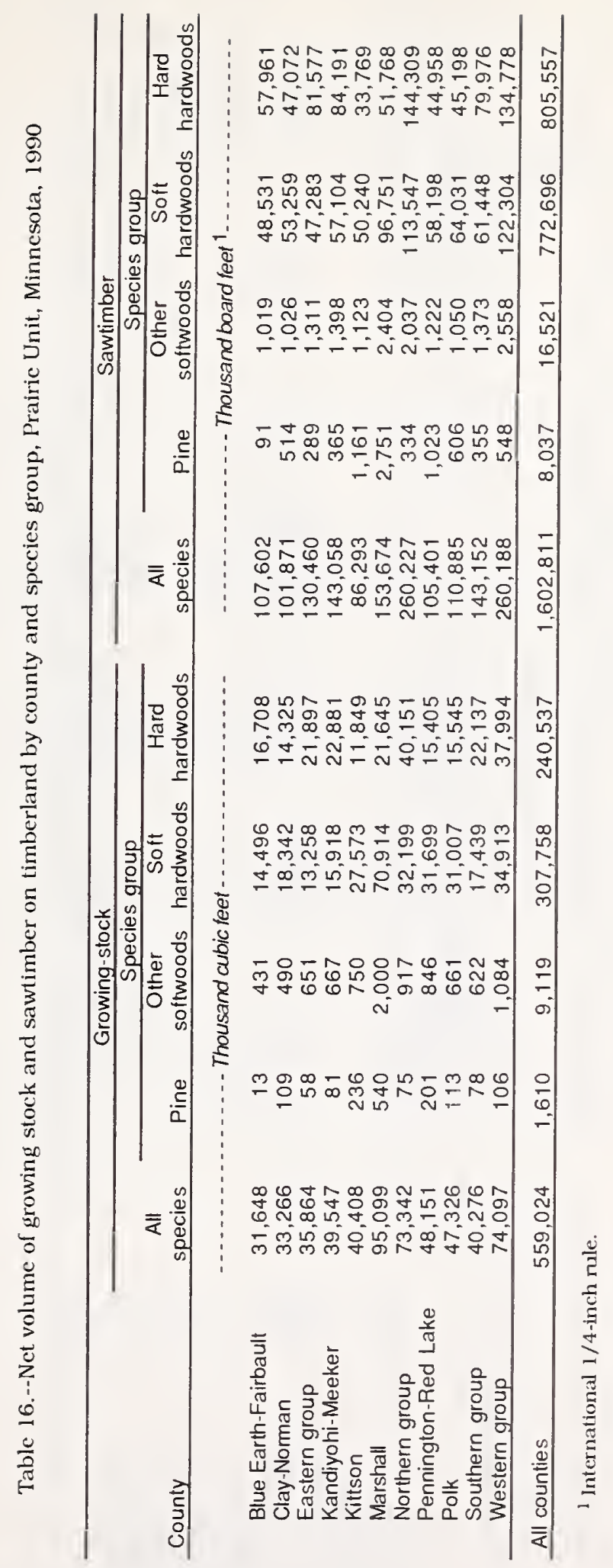




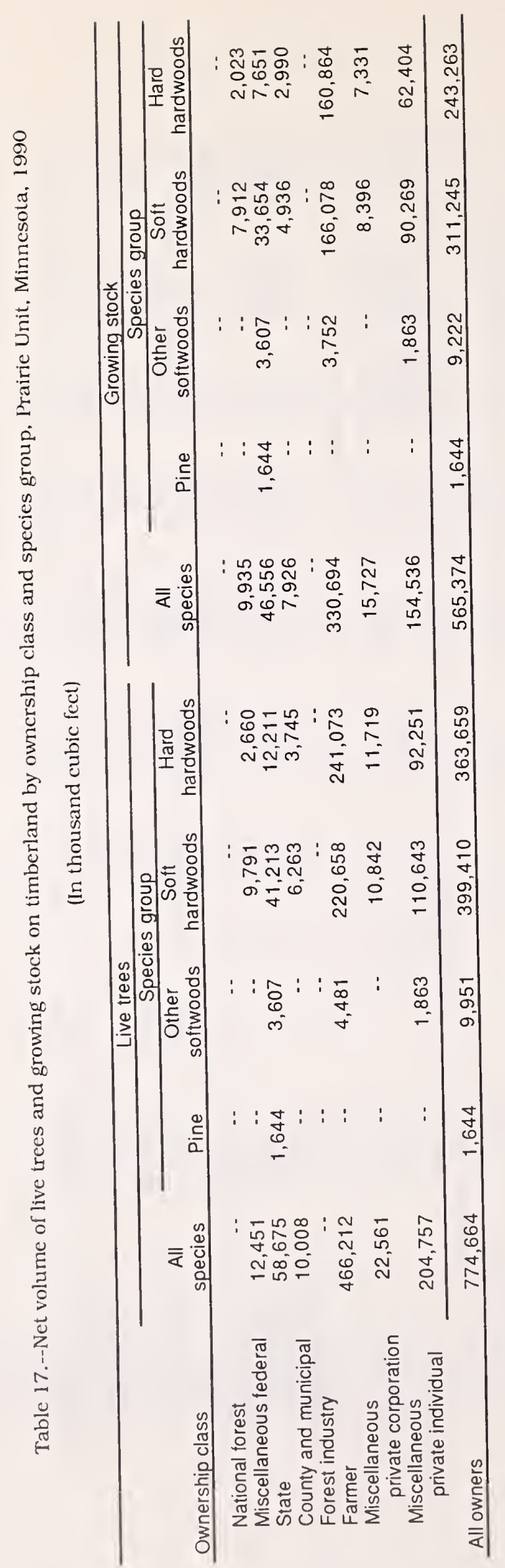


Table 18.--Net volume of sawtimber trees on timberland by species group and butt log grade. Prairie Unit, Minnesota. 1990

(In thousand board feet) ${ }^{1}$

\begin{tabular}{|c|c|c|c|c|c|}
\hline \multirow[b]{2}{*}{ Species group } & \multirow{2}{*}{$\begin{array}{c}\text { All } \\
\text { grades }\end{array}$} & \multicolumn{4}{|c|}{ Butt log grade } \\
\hline & & 1 & 2 & 3 & Tie and timber \\
\hline \multicolumn{6}{|l|}{ Softwoods } \\
\hline Jack pine & 910 & 5 & 59 & 846 & -- \\
\hline Red pine & 3,635 & 370 & 660 & 2,605 & -- \\
\hline White pine & 3,474 & 618 & 1,067 & 1,469 & 320 \\
\hline White spruce & 3,722 & 60 & 267 & 3,395 & -- \\
\hline Black spruce & -- & -. & -. & -- & -- \\
\hline Tamarack & 1,754 & .- & 89 & 1,665 & .. \\
\hline Eastern redcedar & 11,076 & -. & 1,880 & 9,196 & .- \\
\hline Total & 24,571 & 1,053 & 4,022 & 19,176 & 320 \\
\hline \multicolumn{6}{|l|}{ Hardwoods } \\
\hline White oak & 432,501 & 26,682 & 48,016 & 155,495 & 202,308 \\
\hline Select red oak & 107,706 & 4,387 & 26,911 & 47,371 & 29,037 \\
\hline Other red oak & 5,671 & -. & - & 4,571 & 1,100 \\
\hline Hickory & 3,422 & .. & -- & 2,434 & 988 \\
\hline Basswood & 268,487 & 103,959 & 66,334 & 91,539 & 6,655 \\
\hline Yellow birch & & & & & \\
\hline Hard maple & 40,641 & 8,487 & 11,892 & 12,339 & 7,924 \\
\hline Soft maple & 35,811 & 10,970 & 4,897 & 6,093 & 13,850 \\
\hline Elm & 84,054 & 2,635 & 21,169 & 23,531 & 36,719 \\
\hline Black ash & 5,730 & -. & & & 5,730 \\
\hline White and green ash & 170,112 & 27,777 & 38,239 & 79,877 & 24,220 \\
\hline Cottonwood & 131,685 & 25,748 & 36,482 & 54,431 & 15,024 \\
\hline Willow & 57,392 & -. & 7,061 & & 50,331 \\
\hline Hackberry & 11,692 & .. & 4,182 & 7,510 & \\
\hline Balsam poplar & 36,161 & -. & .. & 15,022 & 21,139 \\
\hline Bigtooth aspen & 314 & -- & -- & 106 & 208 \\
\hline Quaking aspen & 142,359 & -. & -. & 47,962 & 94,397 \\
\hline Paper birch & 2,439 & .- & -. & 822 & 1,617 \\
\hline Black cherry & 2,054 & -. & -. & 2,054 & -. \\
\hline Black walnut & 7,701 & .. & 3,497 & 4,204 & .. \\
\hline Butternut & 1,660 & .- & 754 & 906 & -. \\
\hline Other hardwoods & 35,009 & -. & 5,122 & 4,429 & 25,458 \\
\hline Total & $1,582,601$ & 210,644 & 274,556 & 560,694 & 536,706 \\
\hline All species & $1,607,172$ & 211,697 & 278,578 & 579,870 & 537,026 \\
\hline
\end{tabular}

1 International 1/4-inch rule. 


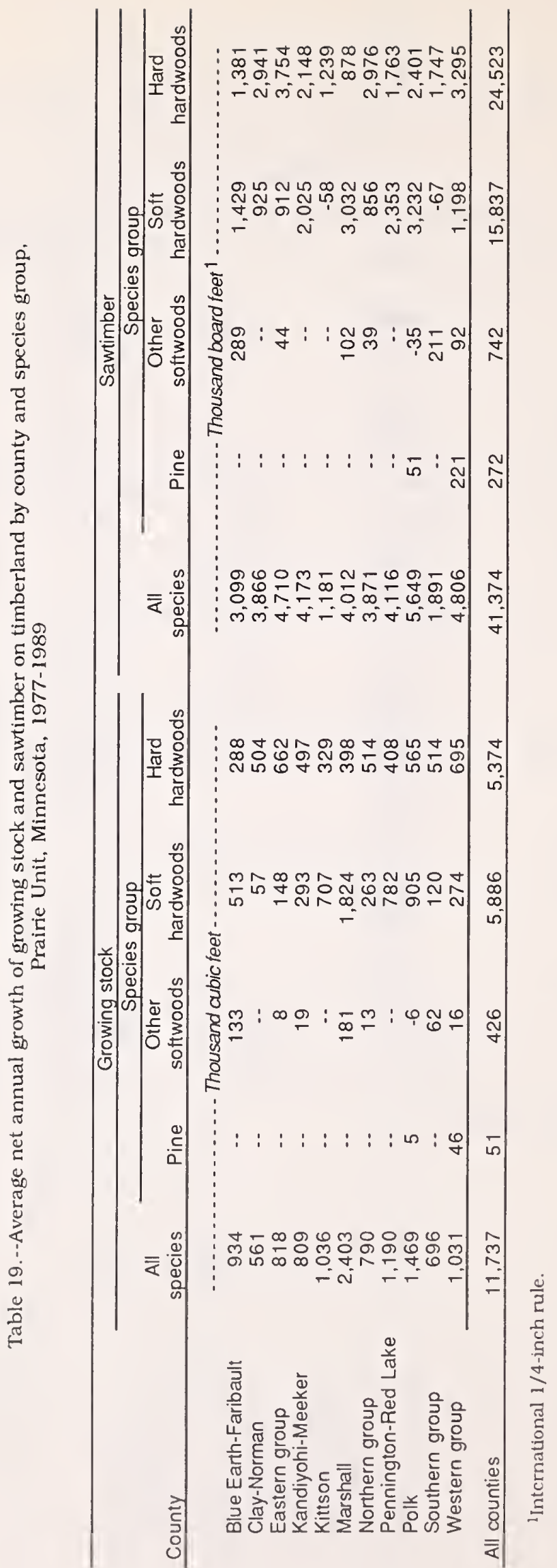




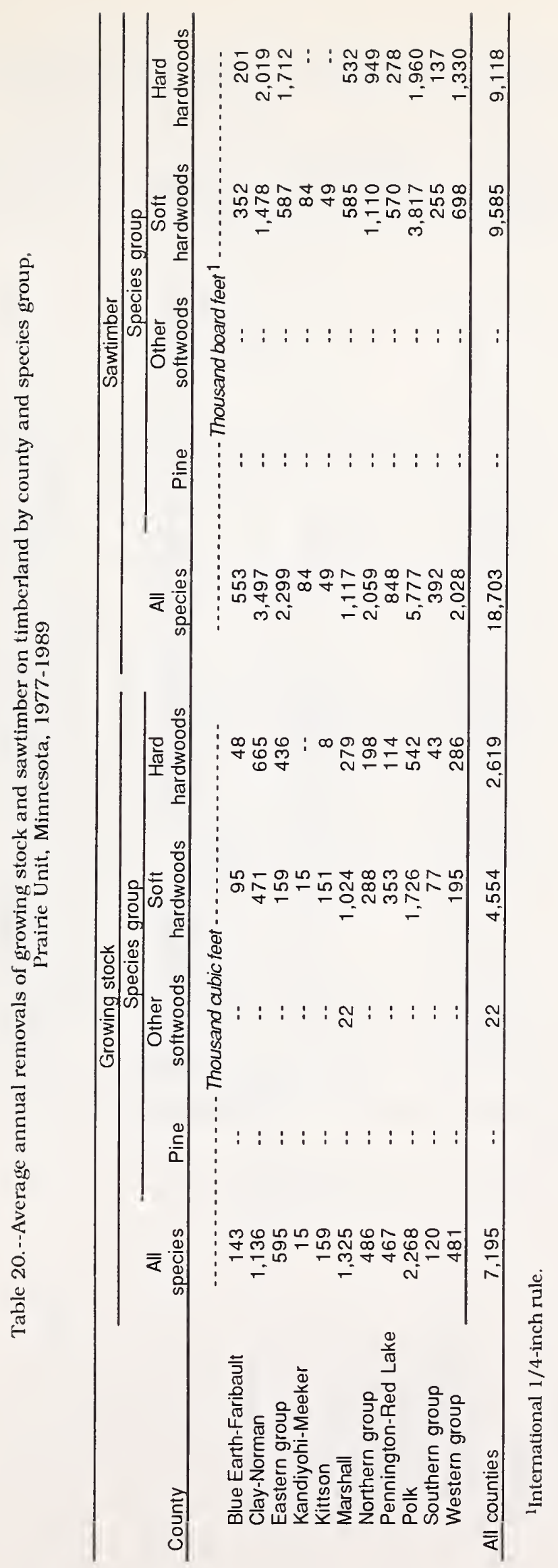


Table 21.--Average net annual growth, mortality, and removals of growing stock and sawtimber on timberland by species group, Prairie Unit, Minnesota, 1977-1989

\begin{tabular}{|c|c|c|c|c|c|c|}
\hline \multirow[b]{2}{*}{ Species group } & \multicolumn{3}{|c|}{ Growing stock } & \multicolumn{3}{|c|}{ Sawtimber } \\
\hline & Net growth ${ }^{1}$ & Mortality & Removals & Net growth ${ }^{1}$ & Mortality & Removals \\
\hline \multicolumn{7}{|l|}{ Softwoods } \\
\hline Jack pine & -7 & 12 & $\ldots$ & -14 & 36 & $\ldots$ \\
\hline Red pine & 15 & - & .. & 81 & -.. & 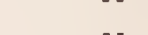 \\
\hline White pine & 43 & .. & - . & 205 & 2 & $\ldots$ \\
\hline White spruce & 17 & 7 & 6 & 92 & 42 & -. \\
\hline Black spruce & 36 & 10 & - & - & . & - \\
\hline Balsam fir & 42 & . & .. & -- & - & -. \\
\hline Tamarack & 96 & 28 & 16 & 67 & 2 & - - \\
\hline Eastern redcedar & 235 & - & -- & 583 & $\cdots$ & - \\
\hline Total & 477 & 57 & 22 & 1,014 & 82 & $\cdots$ \\
\hline \multicolumn{7}{|l|}{ Hardwoods } \\
\hline White oak & 1,885 & 197 & 1,410 & 11,684 & 808 & 4,460 \\
\hline Select red oak & 452 & 218 & 395 & 2,847 & 719 & 1,727 \\
\hline Other red oak & -5 & 25 & 9 & 144 & 71 & 42 \\
\hline Hickory & 79 & 3 & 4 & 181 & 4 & - - \\
\hline Basswood & 1,164 & 370 & 476 & 5,881 & 1,637 & 2,212 \\
\hline Yellow birch & 11 & -- & -- & -- & - & -. \\
\hline Hard maple & 128 & 67 & 72 & 1,136 & 158 & 242 \\
\hline Soft maple & 180 & 14 & 15 & 1,382 & 41 & 84 \\
\hline Elm & $-1,606$ & 3,385 & 950 & $-8,863$ & 11,360 & 3,323 \\
\hline Black ash & 198 & 28 & 56 & 353 & 5 & 33 \\
\hline White and green ash & 1,943 & 180 & 469 & 6,999 & 527 & 2,176 \\
\hline Cottonwood & 705 & 265 & 172 & 4,040 & 835 & 832 \\
\hline Willow & 278 & 200 & 40 & 1,764 & 592 & 136 \\
\hline Hackberry & 197 & 22 & 8 & 323 & 100 & -- \\
\hline Balsam poplar & 894 & 684 & 571 & 1,931 & 780 & 652 \\
\hline Bigtooth aspen & 35 & 1 & - & 21 & 4 & -. \\
\hline Quaking aspen & 3,923 & 2,942 & 2,243 & 9,074 & 2,563 & 2,289 \\
\hline Paper birch & -8 & 98 & 40 & -128 & 128 & -. \\
\hline Black cherry & -26 & 36 & 28 & 203 & 111 & - - \\
\hline Black walnut & 62 & 9 & 7 & 228 & 52 & -- \\
\hline Butternut & 150 & -- & 11 & 209 & 5 & 57 \\
\hline Other hardwoods & 621 & 251 & 197 & 951 & 316 & 438 \\
\hline Total & 11,260 & 8,995 & 7,173 & 40,360 & 20,816 & 18.703 \\
\hline All species & 11,737 & 9,052 & 7,195 & 41,374 & 20,898 & 18,703 \\
\hline
\end{tabular}

${ }^{1}$ An estimate of average gross growth may be computed by adding average mortality to average net growth.

${ }^{2}$ International $1 / 4$-inch rulc. 


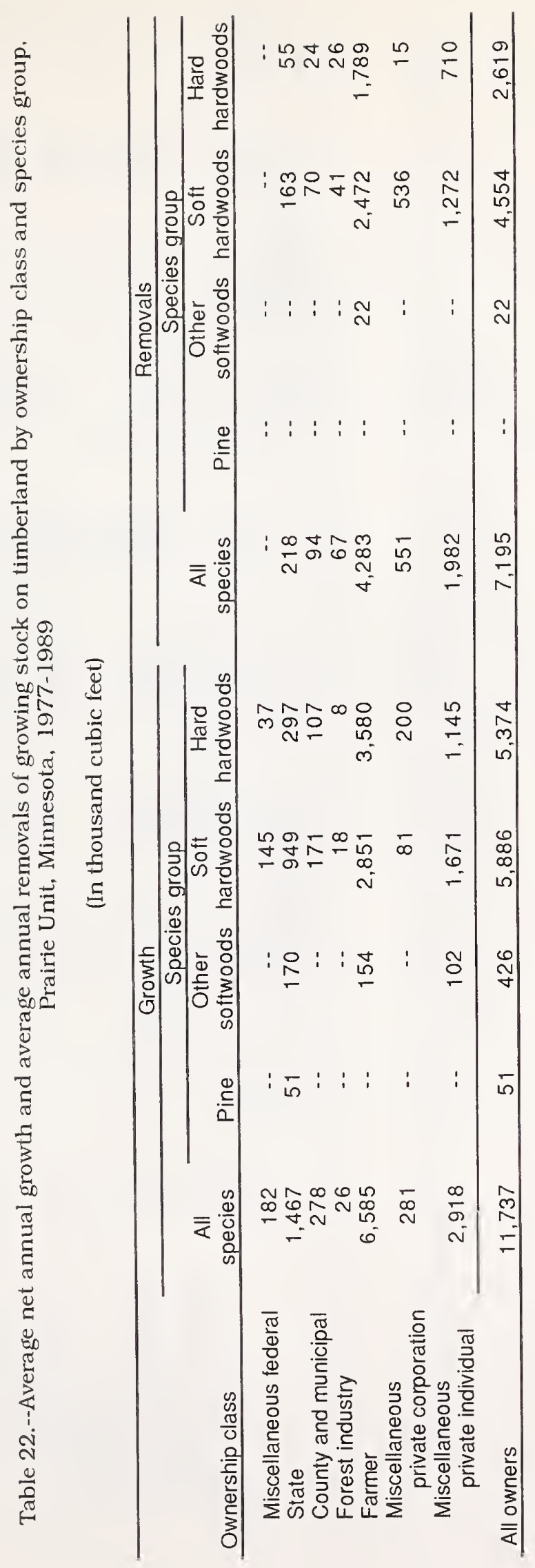




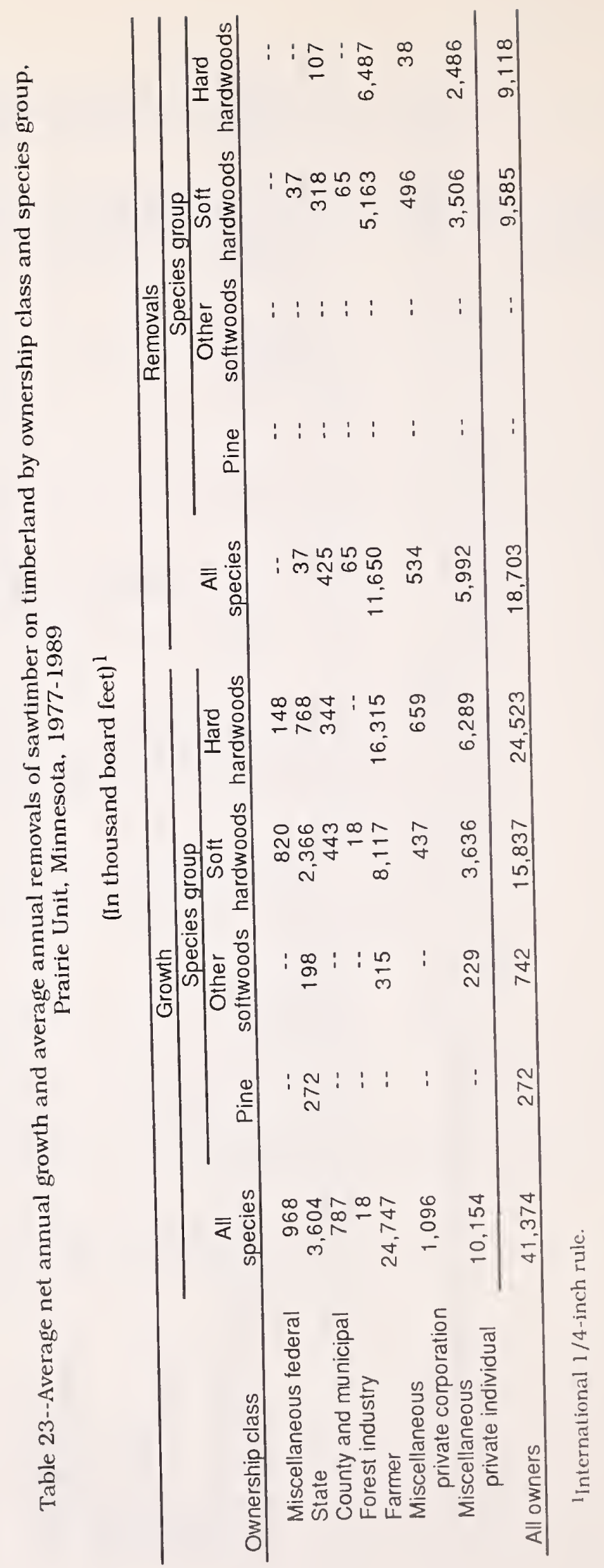


Table 24.--Current annual growth, mortality, and removals of growing stock and sawtimber on timberland by species group. Prairie Unit, Minnesota, 1989

\begin{tabular}{|c|c|c|c|c|c|c|}
\hline \multirow[b]{2}{*}{ Species group } & \multicolumn{3}{|c|}{ Growing stock } & \multicolumn{3}{|c|}{ Sawtimber } \\
\hline & $\begin{array}{c}1989 \\
\text { Net growth } 1 \\
\end{array}$ & $\begin{array}{c}1989 \\
\text { Mortality }\end{array}$ & $\begin{array}{c}1988 \\
\text { Removals } 2 \\
\end{array}$ & $\begin{array}{c}1989 \\
\text { Net growth }{ }^{1} \\
\end{array}$ & $\begin{array}{c}1989 \\
\text { Mortality } \\
\end{array}$ & $\begin{array}{c}1988 \\
\text { Removals } 2 \\
\end{array}$ \\
\hline $\begin{array}{l}\text { Softwoods } \\
\text { Jack pine } \\
\text { Red pine } \\
\text { White pine } \\
\text { Spruce } \\
\text { Balsam fir } \\
\text { Tamarack } \\
\text { Eastern redcedar }\end{array}$ & $\begin{array}{r}-3 \\
15 \\
43 \\
47 \\
51 \\
82 \\
231 \\
\end{array}$ & $\begin{array}{r}6 \\
-- \\
-- \\
20 \\
5 \\
-- \\
28 \\
\end{array}$ & $\begin{array}{r}1 \\
2 \\
1 \\
6 \\
-- \\
19 \\
1\end{array}$ & $\begin{array}{r}-16 \\
81 \\
205 \\
167 \\
-- \\
195 \\
721 \\
\end{array}$ & $\begin{array}{c}30 \\
-- \\
2 \\
1 \\
-- \\
10 \\
--\end{array}$ & $\begin{array}{r}7 \\
15 \\
4 \\
-- \\
-- \\
15 \\
4 \\
\end{array}$ \\
\hline Total & 466 & 59 & 30 & 1,353 & 43 & 45 \\
\hline $\begin{array}{l}\text { Hardwoods } \\
\text { White oak } \\
\text { Red oak } \\
\text { Basswood } \\
\text { Yellow birch } \\
\text { Hard maple } \\
\text { Soft maple } \\
\text { Elm } \\
\text { Ash } \\
\text { Cottonwood } \\
\text { Balsam poplar } \\
\text { Aspen } \\
\text { Paper birch } \\
\text { Other hardwoods }\end{array}$ & $\begin{array}{r}2,572 \\
516 \\
1,282 \\
7 \\
322 \\
235 \\
953 \\
2,475 \\
712 \\
1,083 \\
5,655 \\
35 \\
1,931 \\
\end{array}$ & $\begin{array}{r}19 \\
292 \\
437 \\
3 \\
29 \\
20 \\
802 \\
173 \\
72 \\
647 \\
3,267 \\
47 \\
614 \\
\end{array}$ & $\begin{array}{r}899 \\
281 \\
228 \\
1 \\
311 \\
176 \\
1,033 \\
648 \\
607 \\
541 \\
1,558 \\
32 \\
312 \\
\end{array}$ & $\begin{array}{r}11,785 \\
2,685 \\
5,299 \\
-- \\
1,007 \\
1,302 \\
275 \\
7,916 \\
4,041 \\
2,963 \\
14,934 \\
161 \\
3,941 \\
\end{array}$ & $\begin{array}{r}660 \\
1,129 \\
2,007 \\
-- \\
108 \\
96 \\
2,156 \\
420 \\
332 \\
808 \\
3,472 \\
40 \\
1,421 \\
\end{array}$ & $\begin{array}{r}2,781 \\
1,150 \\
1,122 \\
7 \\
634 \\
500 \\
3,960 \\
2,186 \\
2,922 \\
593 \\
1,918 \\
61 \\
869 \\
\end{array}$ \\
\hline Total & 17,778 & 6,422 & 6,627 & 56,309 & 12,649 & 18,703 \\
\hline All species & 18,244 & 6.481 & 6,657 & 57,662 & 12,692 & 18,748 \\
\hline
\end{tabular}

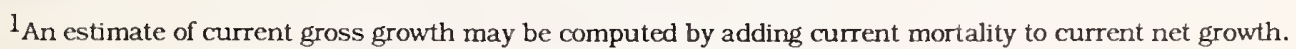

${ }^{2}$ Based on data from a 1988 mill survey and a 1989-1990 logging utilization study, and on land use change estimates from the new inventory.

3International 1/4-inch rule. 

Roussopoulos, Sue M.

1992. Forest statistics for Minnesota's Prairie Unit. Resour. Bull. NC-138. St. Paul, MN: U.S. Department of Agriculture, Forest Service, North Central Forest Experiment Station. 45 p.

The fifth inventory of Minnesota's Prairie Unit reports 19.2 million acres of land, of which 660 thousand acres are forested. This bulletin presents statistical highlights and contains detailed tables of forest area, as well as timber volume, growth, removals, mortality, and ownership.

KEY WORDS: Forest area, timber volume, growth, removals, mortality. 
Our job at the North Central Forest Experiment Station is discovering and creating new knowledge and technology in the field of natural resources and conveying this information to the people who can use it. As a new generation of forests emerges in our region, managers are confronted with two unique challenges: (1) Dealing with the great diversity in composition, quality, and ownership of the forests, and (2) Reconciling the conflicting demands of the people who use them. Helping the forest manager meet these challenges while protecting the environment is what research at North Central is all about. 